\section{OTRO ENIGMA DE EL GRECO: ¿UN PINTOR ESCÉPTICO QUE REALIZA PINTURA RELIGIOSA?}

\author{
Alfonso Rodríguez G. de Ceballos \\ Real Academia de Bellas Artes de San Fernando \\ alrodriguez_ceballos@wanadoo.es
}

Cómo citar este artículo/Citation: Rodríguez G. de Ceballos, A. (2015). "Otro enigma de El Greco: ¿un pintor escéptico que realiza pintura religiosa?". Arbor, 191 (776): a280. doi: http://dx.doi. org/10.3989/arbor.2015.776n6007

Recibido: 22 diciembre 2014. Aceptado: 9 marzo 2015.

RESUMEN: Frente a la opinión reciente, El Greco no solo fue pintor de amplísima obra religiosa, sino personalmente de arraigadas convicciones religiosas, tanto como miembro de una familia de fe ortodoxa como también después de su paso al catolicismo romano, como lo demuestran muchos episodios y acontecimientos de su vida y muerte. Avalan esta suposición tanto la correcta y tradicional iconografía de su pintura sacra, cuanto muchas de las características ideológicas, técnicas y expresivas de su obra.

PALABRAS CLAVE: pintura religiosa; Iglesia ortodoxa griega; fe católica romana; iconografía religiosa; Porfirio Plotino; PseudoDionisio areopagita.

\section{ANOTHER OF EL GRECO'S ENIGMAS: A SKEPTICAL PAINTER DOING RELIGIOUS PAINTING?}

Copyright: (C) 2015 CSIC. Este es un artículo de acceso abierto distribuido bajo los términos de la licencia Creative Commons Attribution-Non Commercial (by-nc) Spain 3.0.
ABSTRACT: Contrary to current opinion, El Greco was not only a prolific painter of religious pictures, but also person of entrenched beliefs both as a member of an Orthodox family, and when he converted to the Roman Catholic faith, as is clear from many episodes and events in his life and death. This hypothesis is borne out by the correct and traditional iconography in his religious paintings, and in the ideological, technical and expressive aspects of his work.

KEYWORDS: religious painting; Greek Orthodox Church; Roman Catholic faith; iconography; Porfirius Plotinus; Dionysius the Aeropagite. 
Desde finales del siglo XIX EI Greco ha obtenido por parte de la crítica una nueva dimensión: precursor de la pintura contemporánea en virtud de su singular técnica y de su concepto del arte como creación autónoma e independiente. Uno de los más entusiastas formuladores de esta formulación fue el alemán Julius Meier Gräfe, quien para ensalzar al pintor cretense llegó a anteponerlo a Velázquez, rebajando a este al nivel de un simple artesano, a un naturalista del calibre más burdo que únicamente sabía retratar la realidad perceptible por los ojos. El Greco, en cambio, como si se tratara de un genio desvinculado a la manera romántica de las coordenadas de tiempo y espacio, habría transformado su pintura en una suerte de valor universal y atemporal, abriendo el camino al cultivo del arte por el arte. Aunque reconocía en el cretense a un neoidealista, a la manera de Cézanne, superador del impresionismo y esencialista, no tenía en cuenta para nada los asuntos y los clientes para quienes pintó El Greco y, por ello, hacía caso omiso en su pintura de toda impronta religiosa, pese a que trabajó la mayor parte de su vida en Toledo, capital espiritual de España, y a que se esforzó en poner a punto la denominada por Hubert Jedin "Reforma Católica", coincidiendo casi exactamente con el reinado de Felipe II $^{1}$.

Desde la celebración en Madrid y Toledo, entre abril y junio de 1982, de las grandes exposiciones sobre El Greco y del coloquio internacional sobre su pintura en Italia y España, muchos de los comisarios, ponentes y asistentes comenzaron a diseñar una visión distinta del cretense, superadora de la ofrecida en 1908 por Manuel Bartolomé Cossío, a la que se habían atenido los supervivientes de la generación de 1908, los intelectuales salidos de la Institución Libre de Enseñanza e incluso muchos miembros de la generación de 1927, como quedó reflejado en el lienzo, a lápiz y carboncillo, de Ignacio Zuloaga, en el que figuran, sentados como dialogando ante la pintura grequiana Apertura del Último Sello: Miguel de Unamuno, Pío Baroja, Azorín, Ramón Perez de Ayala, Vicente Blasco Ibáñez, Gregorio Marañón y el propio Zuloaga, propietario entonces del misterioso cuadro del cretense (Fig.1). Cossío había ofrecido una versión de El Greco completamente hispanizado gracias al ambiente semítico-oriental, levítico y decadente de que se empapó en Toledo y que cultivó una pintura visionaria y espiritualizada, que vino a ser el contrapunto y traducción a términos pictóricos, de la literatura mística contemporánea de santa Teresa y san Juan de la Cruz.

La nueva interpretación de la vida y obra de Theotocópuli que se difundió ampliamente a partir de 1982
Figura 1. Ignacio Zuloaga: Mis amigos, 1920-1936. Zumaya, Espacio Cultural Ignacio Zuloaga

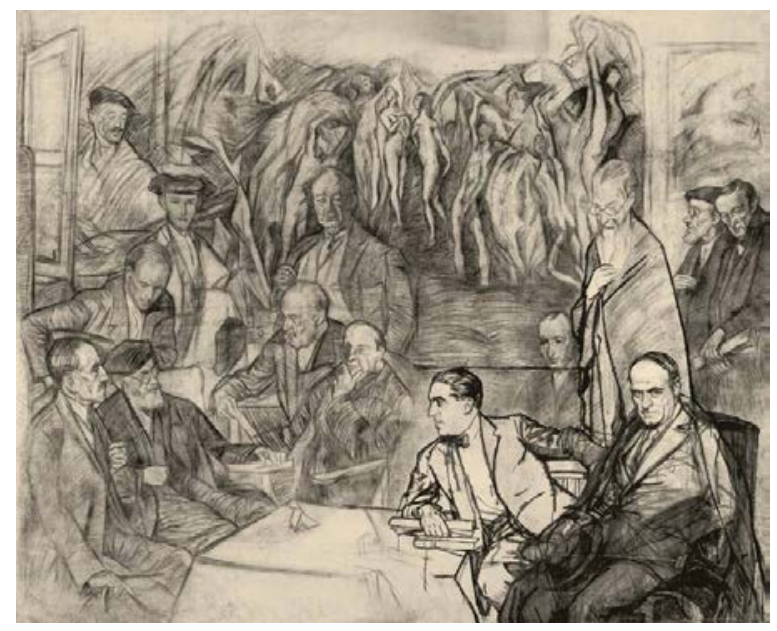

y que recientemente se ha visto reforzada con motivo de la multitudinaria celebración del cuarto centenario de su muerte, tuvo su fuente en el rupturista libro publicado en 1981 por los profesores Fernando Marías y Agustín Bustamante, Las ideas artísticas de El Greco, a raíz del sensacional descubrimiento de las "marginalia" o comentarios del artista, escritos en un español trufado de italianismos difícilmente comprensible, en los márgenes del tratado de arquitectura del romano Marco Vitrubio Polión, editado por Daniele Barbaro, y posteriormente en los de las Vidas de los artistas italianos, de Giorgio Vasari, que le había regalado F. Zuccari con motivo de la visita que hizo a Toledo. De ello resultaría que El Greco fue "un filósofo de agudos dichos", como ya lo había calificado Francisco Pacheco en 1646, que era capaz de disertar aguda y conceptuar sutilmente sobre todas las artes en un lenguaje similar al de sus culteranos amigos Luis de Góngora y Felix Hortensio de Paravicino, del que deducía que su pintura estaba basada sobre dichos conceptos estéti$\cos$ y no sobre la ideología cristiana, utilizada meramente como referencia a los contenidos iconográficos de algunos de sus cuadros religiosos. Además era persona desmotivada de las convenciones morales al uso, pues vivía amancebado con Jerónima de las Cuevas, a quien en su testamento mencionó solo como madre de su hijo Jorge Manuel, no ordenó funerales y entierro conforme a los ritos acostumbrados por la Iglesia, era manirroto, ostentoso y amante del lujo, soberbio y tercamente independiente tanto en su vida como en pintura y en las mencionadas "marginalia" no expresó opinión alguna sobre temas religiosos. 
Como consecuencia de todo ello El Greco no fue el "místico" de suponía Cossío -lo que es absolutamente cierto, desde luego- , sino un cristiano vulgar, rutinario, tibio, seguramente escéptico o, en todo caso, asépticamente religioso. Ya F. Marías había comentado como irreverente y bordeando la blasfemia el comentario del cretense a propósito del aserto de que las proporciones visuales tendrían que ser reguladas por las ciencias geométrico-matemáticas, a saber: "Que las Mathematicas lo abrazan el todo, como el Christus, la scientia no se niega, pues tanta parte tienen los matemáticos en estas Artes como el que tendrá el otro en las scientias por saber el Christus" (Marías y Bustamante, 1981, p. 239).

A mi modo de entender en la comparación que hace entre los matemáticos y los clérigos que manejan "el Christus", este término no lo entendió El Greco como la persona de Jesucristo, sino como sinónimo del "catecismo" que sintetiza la doctrina de la Iglesia, que algunos teólogos, por haberlo escrito, creían poseer la clave del conocimiento de todo lo humano y lo divino, al igual que los matemáticos, por el hecho de dominar su especialidad científica, juzgaban que para determinar las proporciones de las figuras, bastaban las matemáticas. Téngase en cuenta para comprender esta curiosa comparación que el catecismo que el Concilio de Trento había mandado componer como síntesis de la doctrina católica frente a la luterana, se publicó en Roma finalmente en 1566 durante el pontificado de Pio V, redactado por teólogos dominicos, precisamente el año en que el Theotokopuli se disponía a abandonar Venecia, donde entonces se encontraba, para encaminarse a Roma. Por ello El Greco bien sabía lo que era el catecismo y acaso el uso abusivo que hacían de su lectura algunos clérigos. Por otra parte, estoy convencido de que para ser un buen pintor religioso, no hace falta ser ningún ñoño o mojigato, como a veces supuso $A$. Palomino que lo eran algunos artistas españoles, como Juan de Juanes o Gregorio Fernández. Estoy seguro de que para ello es suficiente creer y sentir sinceramente lo que se pinta o esculpe, al modo y manera como cada uno entiende y practica la vivencia religiosa, sin necesidad de rezar o comulgar antes de emprender la hechura de una obra devocional.

Pero vayamos por partes. Una ojeada a los tres lugares más importantes en que se desarrolló la vida y obra de El Greco, Candía, Venecia y Toledo, debe ayudarnos a comprender el poso y la huella permanente que dejaron en su pintura estos lugares, lo que de paso contribuirá a dilucidar el enigma propuesto. Nacido el año 1541 en Candía (Creta), entonces bajo el dominio de
Figura 2. El Greco: Autorretrato? 1595-1600. Nueva York, The Metropolitan Museum of Art.

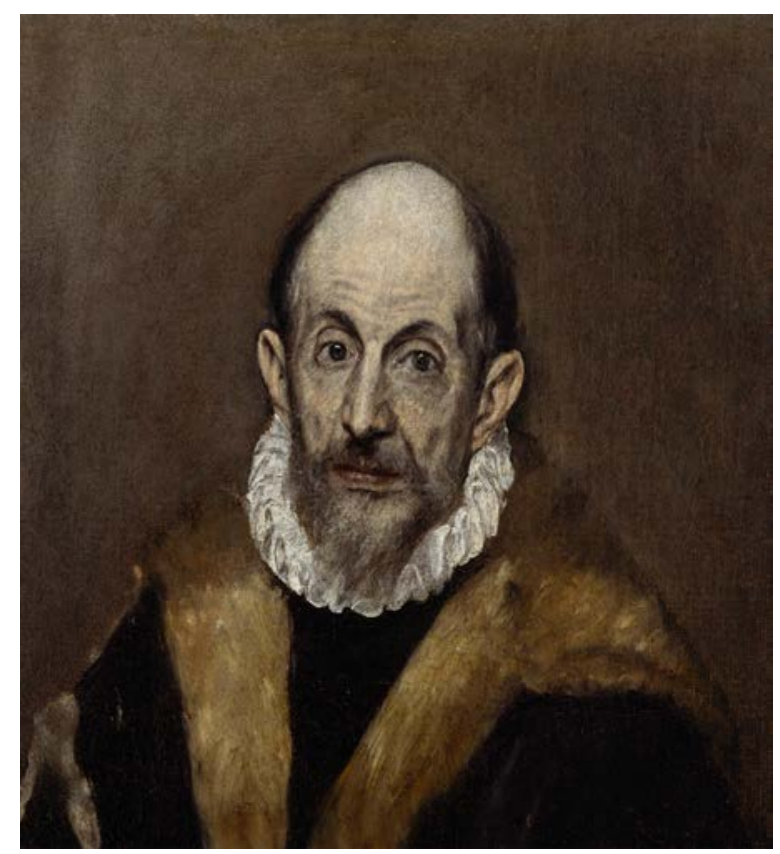

la república de Venecia, fue hijo de Giorgios o Zorzi en dialecto veneciano, acomodado comerciante y marino, perteneciente al clan de los Theotocopuli, una familia en la que, según los documentos, todos sus miembros aparecen censados como de religión griega ortodoxa. Se le puso por nombre Doménicos, un vocablo de raíz latina, mientras que el apellido Theotocópuli parece ser el genitivo de Theotocópulos, que a su vez entronca con el término griego Theotócos, con el que fue designada la Virgen María como Madre de Dios en el Concilio ecuménico de Éfeso (431 d. C.). Parece, pues, presumible que toda la familia fuera devota de la Virgen con esta trascendental invocación. Fallecido su padre en 1566, el joven Doménicos quedó bajo la tutela de su hermano Manoussos (Manuel), once años mayor que él, quien era funcionario de la república veneciana como arrendatario contratista de los impuestos arancelarios que la república cobraba sobre las mercancías y productos que entraban y salían del puerto candiota. Es cierto, como afirma el historiador griego N. Panayotakis, que el dominio veneciano sobre la isla de Creta no transcurrió sin oposición de los nativos e incluso que los cretenses siempre fueron considerados por los venecianos como rebeldes, pues se consideraban súbditos naturales del imperio bizantino, cuya religión ortodoxa practicaban poniéndola como bastión de su identidad política. Sin embargo en la época en que vivió El Greco en Creta se había llegado a una "entente" bastante cordial entre ca- 
tólicos latinos y ortodoxos griegos, pues las viejas disputas dogmáticas se habían dulcificado gracias al Concilio de Florencia (1438-1439) y con frecuencia los cretenses ortodoxos asistían a los cultos latinos así como muchas familias de funcionarios venecianos católicos se personaban en los de la iglesia griega. En resumidas cuentas, parecía haberse llegado a una suerte de síntesis de la que podría ser símbolo la pintura neobizantina de iconos, donde la rigidez y hieratismo propios del concepto ortodoxo de la imagen sagrada, se había combinado con la técnica más dúctil y suave de la pintura veneciana. También la misma combinación del nombre y apellido de El Greco, el uno de origen latino y el otro griego, parecen reflejar la misma simbiosis.

El cardenal Besarión, fautor del Concilio de Florencia, había fundado una escuela en Candía el año 1462 para la enseñanza de los Griegos Uniatas, en la cual, por su elitismo y calidad, solían estudiar escolares ortodoxos, acaso el propio Doménicos, que en ella recibiría la instrucción en las primeras letras. Manoussos, que manejaba una considerable fortuna, costeó el aprendizaje pictórico de su hermano, que daba precoces signos de gran habilidad para el dibujo, en el taller de iconos regentado por Dimitrios Klontzas, quien fuel el que mejor manejó el mestizaje entre la tradición griega y la novedad veneciana. Dada, por otro lado, la connivencia y la escasa diferencia entre ambas iglesias, el mencionado historiador griego piensa que el paso a la iglesia católica romana fue dado por los dos hermanos simultá- neamente en vísperas de trasladarse a Venecia, acaso para congraciarse con el nuevo ambiente en que cada uno, en su ramo, pensaban mejorar y adelantar en su carrera $^{2}$. El propio Panayotakis señala otros puntos de interés para nuestro asunto. Así sabemos que Doménicos era de fuerte y apasionado carácter y un asiduo y testarudo pleiteador ya en sus años de juventud en Creta, por lo que no nos debe extrañar que lo continuase siendo cuando se estableció definitivamente en España. Por otro lado, una curiosa aventura de su hermano Manuossos también nos ilustra de cómo era esta arriesgada familia de los Theotocópuli (Fig.3). Resulta que, después de varias tentativas, consiguió de las autoridades venecianas que fletaran una nave a su mando para vigilar la costa de Dalmacia en el mar Tirreno, por donde transitaban galeotas procedentes del oeste de Italia que comerciaban y a veces transportaban pertrechos para la armada turca. El propósito de Manoussos era apoderarse del cargamento de las naves que abordara y de arrestar a los tripulantes para venderlos como esclavos. Fracasó en este peligroso empeño, pero esta aventura nos recuerda que el vil tráfico de esclavos en el Mediterráneo no era solo fabuloso negocio para los otomanos sino también para los venecianos, si bien es verdad que eran los turcos y sus aliados quienes lo practicaban a mayor escala. Manoussos y Doménicos pienso que llegarían a persuadirse, sobre todo después de la victoria naval de Lepanto en 1571, que únicamente España tenía capacidad para enfrentarse seriamente

Figura 3. Jorge Manuel Theotocópuli: La familia de El Greco. Madrid, Real Academia de Bellas Artes de San Fernando

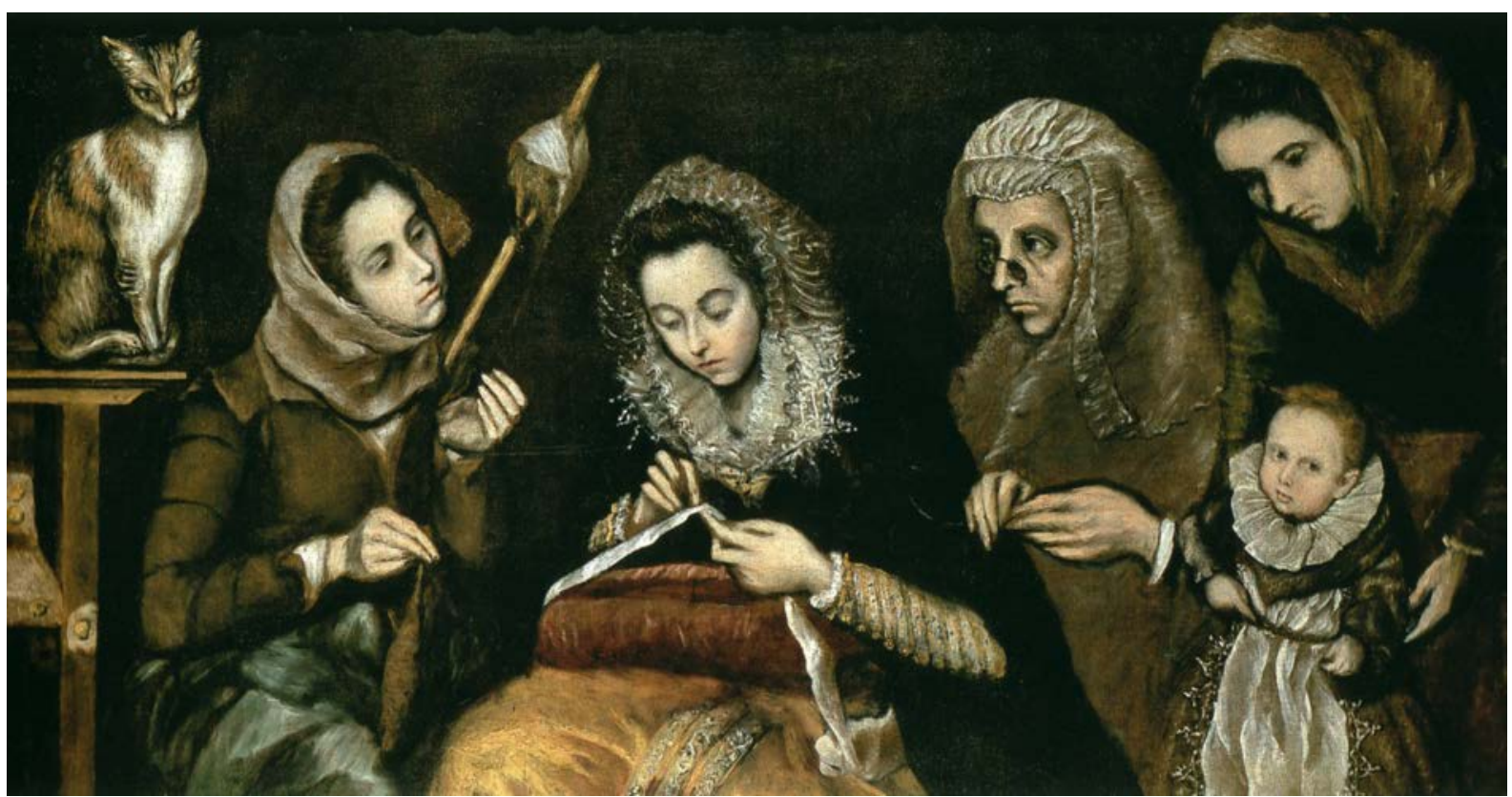


al imperio otomano y poner coto a tan sucio negocio. $Y$ efectivamente, ambos terminarían estableciéndose en nuestro país en diferentes fechas y por distintos caminos. Cerraré esta primera etapa de la vida del pintor cretense indicando que un hijo de Manoussos fue en Candía sacerdote de la iglesia ortodoxa, así como lo sería de la católica el nieto primogénito de Doménicos en España, fray Gabriel Theotocopuli, hijo del primer matrimonio entre su hijo Jorge Manuel y su primera esposa Alfonsa de los Morales (Fig.3).

Poco me voy a detener sobre la presencia de El Greco en Venecia y en Roma durante el período que corre entre 1567 y 1576, pero sí lo suficiente para decir que aquella coincidió en su mayor parte con el pontificado de San Pío V (1566-1572), riguroso reformador de la iglesia católica, empeñado como pocos en su integridad y purificación, así como principal impulsor de la Santa Liga, que coaligó las fuerzas navales de España, Venecia y los Estados Pontificios para derrotar a los turcos en la batalla de Lepanto el 7 de octubre de 1571. Durante esta segunda etapa de su vida, Theotocópuli pintó varios lienzos alusivos a estas distintas iniciativas del pontífice romano. En primer lugar tres variantes pictóricas sobre el mismo tema: La curación del ciego de nacimiento, narrada en el evangelio de San Juan, hoy en los museos de Dresden, Parma (Fig.4) y Nueva York. El profesor L. Puppi opinó que en los tres cuadros Theotocópuli aludió veladamente a su propia "iluminación" que le hizo abandonar la ceguera ortodoxa y convertirse al catolicismo, conversión que habría tenido lugar durante este período. Con todo, las interpretaciones de estos lienzos no son unánimes, sobre todo del de la Galería de Parma, por la presencia en él, en su margen izquierdo, del retrato de un joven contemporáneo que viste con golilla al cuello, que para unos es el de don Juan de Austria y, por ello, una referencia o guiño a la batalla naval de Lepanto, para otros el retrato del joven duque Alejandro Farnese, que habría sido introducido por el pintor para congraciarse con él en vísperas de trasladare a Roma, donde efectivamente solicitaría hospedarse en su famoso palacio concluido por Miguel Ángel (Fig.5).

Figura 4. El Greco: Curación del ciego de nacimiento, 1570-1571. Dresde, Gemäldegalerie Alte Meister.

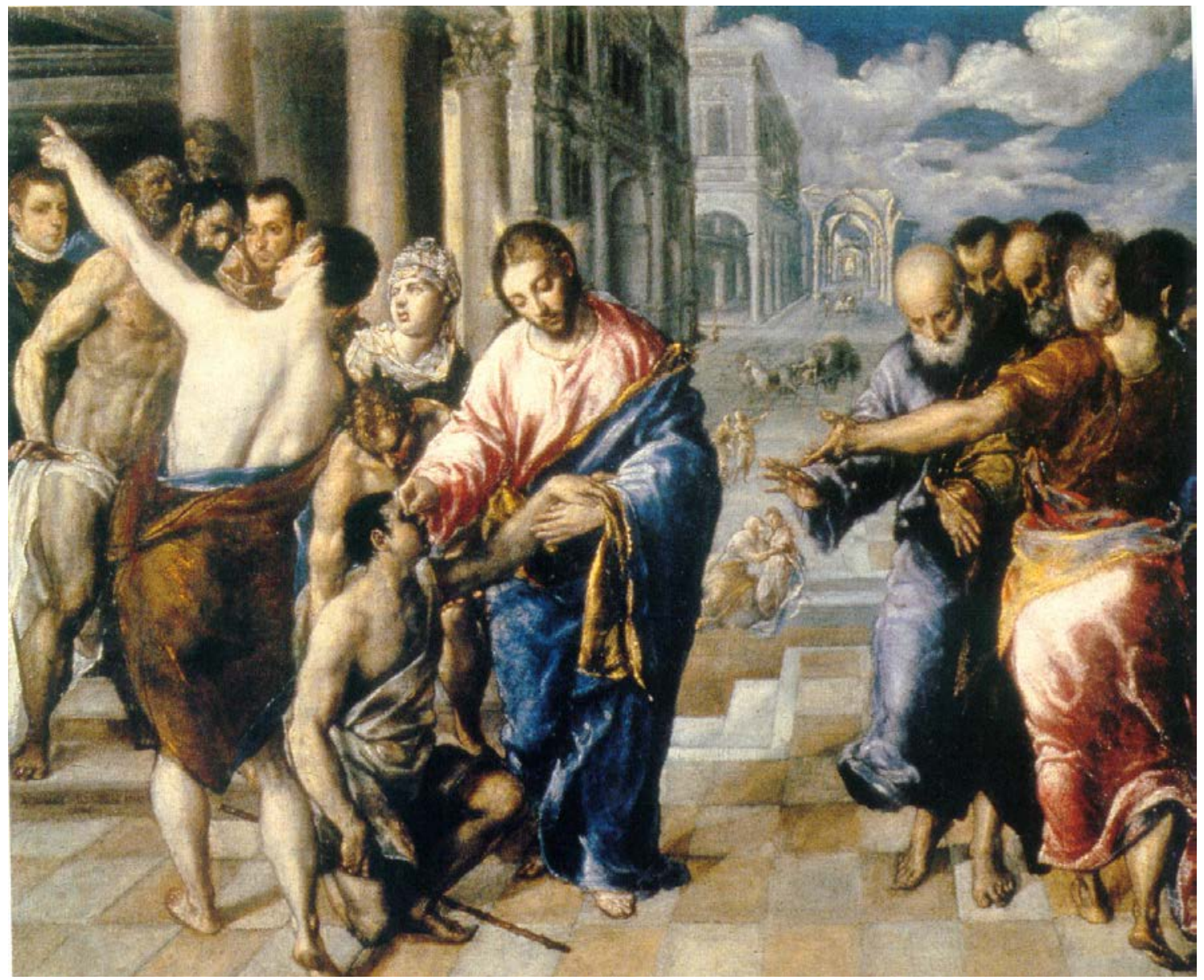


Figura 5. El Greco: Expulsión de los mercaderes del templo, 1572-1573. Minneapolis, Institute of Art

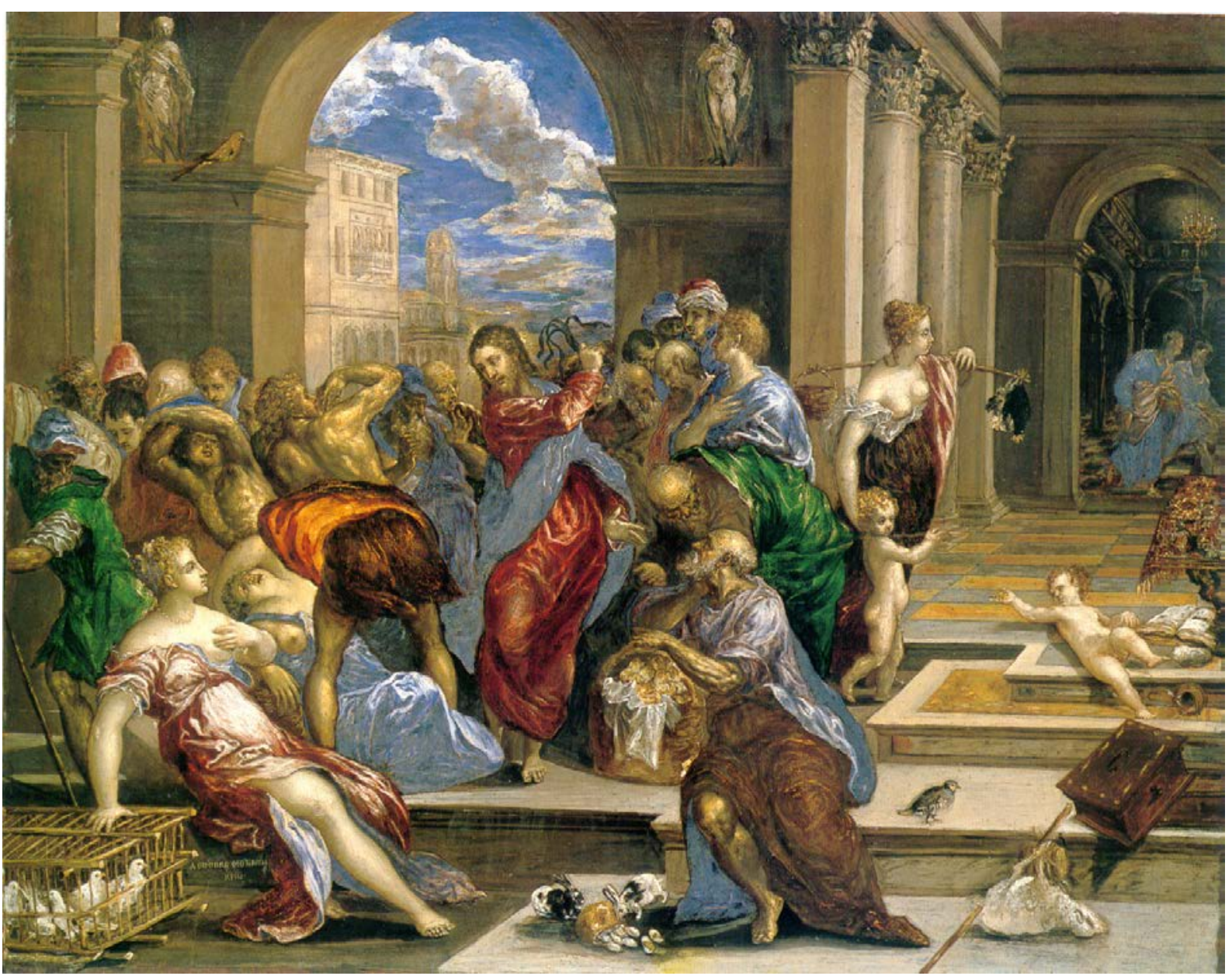

Prefiero, sin embargo, atenerme a la antigua y menos hermética interpretación de $\mathrm{H}$. Wethey, para quien la clave de ella consiste en considerar la curación del ciego de nacimiento como una alegoría de la iglesia, sucesora de Cristo, revelando la verdadera fe, tanto a los paganos como a los cristianos cegados por los distintos movimientos heréticos surgidos contemporáneamente en Europa. También este estudioso norteamericano interpretó, a la luz de la Reforma Católica consolidada por el Concilio de Trento, el otro tema de la segunda serie de tres cuadros del cretense: Cristo expulsando a los mercaderes del templo de Jerusalén. Según él, se trata de otra alegoría cuya clave sería la Iglesia, sucesora de Cristo, purificando los templos de la simonía y de la venta de cargos eclesiásticos. Se fundó para dicha interpretación en que la expulsión de los mercaderes del templo jerosolimitano fue el asunto seleccionado por varios papas reformadores, Paulo IV, Pío V y más tarde Gregorio
XIII, para hacerlo acuñar en las medallas conmemorativas de sus respectivos pontificados ${ }^{3}$. Fue este un tema preferido de El Greco, que volvió a repetir reiteradamente durante su estancia en Toledo, pues en los dos inventarios efectuados por Jorge Manuel tras la muerte de su padre, se mencionan hasta siete pinturas suyas, entre originales y copias, hechas en diferentes formatos. Alguno de estos fue propiedad de uno de los mejores amigos y clientes del cretense, el canonista Pedro Salazar de Mendoza, pues era propietario de "Un quadro de Nuestro Señor cuando echa a los tratantes del Templo" que colgaba en su despacho (Kagan, 1984, p. 87). El motivo de la adquisición o encargo del cuadro por Salazar de Mendoza fue el que este se distinguió, durante el arzobispado en Toledo del cardenal Fernando Quiroga, en haber expulsado de la curia eclesiástica toledana a todos los laicos que habían adquirido oficios administrativos mediante tratos y negocios simoníacos. 
Acogido por breve tiempo en Roma en el palacio Farnese, debió pronunciar allí, en presencia del grupo de eminentes humanistas protegidos por el cardenal Alejandro, palabras muy despectivas sobre la pintura del Juicio Final de Miguel Ángel en la Capilla Sixtina, que transmite Giulio Mancini: "Se si butasse a terra tutta l'opera io l'habrebbe fatta con honestà e decenza e non inferiore a quella in bontá de pittura" (Maio, 1978, p. 19). Hervía entonces en los círculos intelectuales de Roma la discusión sobra la posible demolición del fresco de Miguel Ángel que preparaba el riguroso San Pío $\checkmark$ y por ello se polemizaba sobre el grado de decoro y decencia con que se habían de pintar los asuntos religiosos, polémica que venía de lejos pero que se había agudizado con motivo del decreto en 1563 del concilio tridentino sobre las imágenes sagradas. La opinión de El Greco sobre este punto era clara, contundente y totalmente conforme con las prescripciones conciliares, como se desprende del párrafo de Mancini, y posiblemente fue en estas circunstancias cuando el cretense adquiriría en Roma el volumen los decretos del Concilio de Trento que figuraba en su biblioteca ${ }^{4}$. Su despreciativo comentario sobre el fresco miguelangelesco debió escandalizar y ofender a quienes lo escucharon, pero no fue este el motivo por el que se vio obligado a abandonar Roma, pues continuó en la ciudad por algún tiempo, donde se matriculó como pintor en la Academia de San Lucas, abrió taller y realizó sobre todo retratos. De todos modos las perspectivas de trabajo no debieron resultarle tan halagüeñas como se había prometido, lo que seguramente le impulsó a dirigirse a España, donde sabía que el poderoso monarca Felipe II, vencedor de Lepanto, andaba buscando artistas italianos para completar el programa pictórico del monasterio de El Escorial.

Sin embargo, recién llegado a la península, no fue en El Escorial donde comenzó a trabajar, sino en Toledo, en los retablos y pinturas del convento de Santo Domingo el Antiguo, contratados por don Luis de Castilla, a quien había conocido en Roma, hijo del deán de la catedral, don Diego de Castilla, quien había transformado la iglesia del convento en su capilla funeraria. Pero seguramente su meta final no era Toledo, sino el monasterio filipino, y por eso debió hacer para Felipe II un cuadro de presentación, cuyo tema no podía ser otro que un guiño a la batalla naval de Lepanto, pese a que lo enmascarara representado ingeniosamente en él La adoración del nombre de Jesús, según la carta de San Pablo a los Filipenses, 2, 10: "Al nombre de Jesús toda rodilla se doble en el cielo, en la tierra y en los abismos". En este los adoradores en la tierra son los protagonistas de la Santa Liga: el dux Mocenigo, San
Pio V, Felipe II y su hermanastro don Juan de Austria, que acababa de fallecer en Flandes el año 1679 (Fig. $6)$. Esto quiere decir que Felipe II conocía de antemano la pintura del cretense y debía estimarla, aunque no fuese por otra razón que la de presentarse El Greco como alumno del gran Tiziano. Y así lo afirma el cronista de El Escorial, José de Sigüenza, cuando escribe que "sabe mucho [El Greco] y se ve en cosas excelentes de su mano". Pero cuando le encargó finalmente un cuadro de altar para la basílica de El Escorial, El martirio de San Mauricio (Fig.7), lo rechazó no porque no le complaciera como obra de arte, sino como pintura religiosa destinada al culto público, pues su composición enrevesada y nada clara no cumplía el requisito fundamental de que su asunto fuese fácil e inequívocamente entendido por los fieles. Se han tergiversado excesivamente las palabras del mencionado Sigüenza, en las que da cuenta de este episodio, sobre todo la frase final de que los cuadros de El Greco "quitan la gana de rezar en ellos" (Sigüenza, 1963, p. 385), como si con esto hubiera querido significar que El Greco fuera incapaz de sentir fuego y emoción cuando realizaba pintura religiosa y de comunicar esa emoción empáticamente a los que contemplaban sus cuadros.

Figura 6. El Greco: Adoración del nombre de Jesús y la Santa Liga, 1579-1582. Real Monasterio de San Lorenzo de El Escorial.

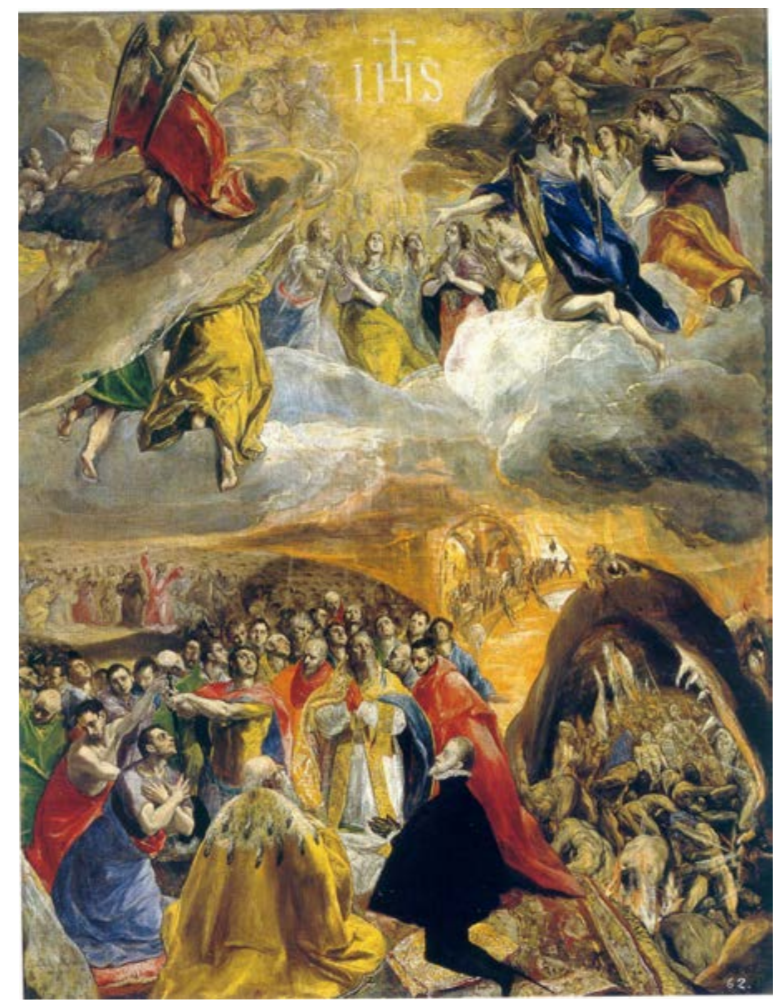


Figura 7. El Greco: Martirio de San Mauricio, 15801582. Real Monasterio de San Lorenzo de El Escorial.

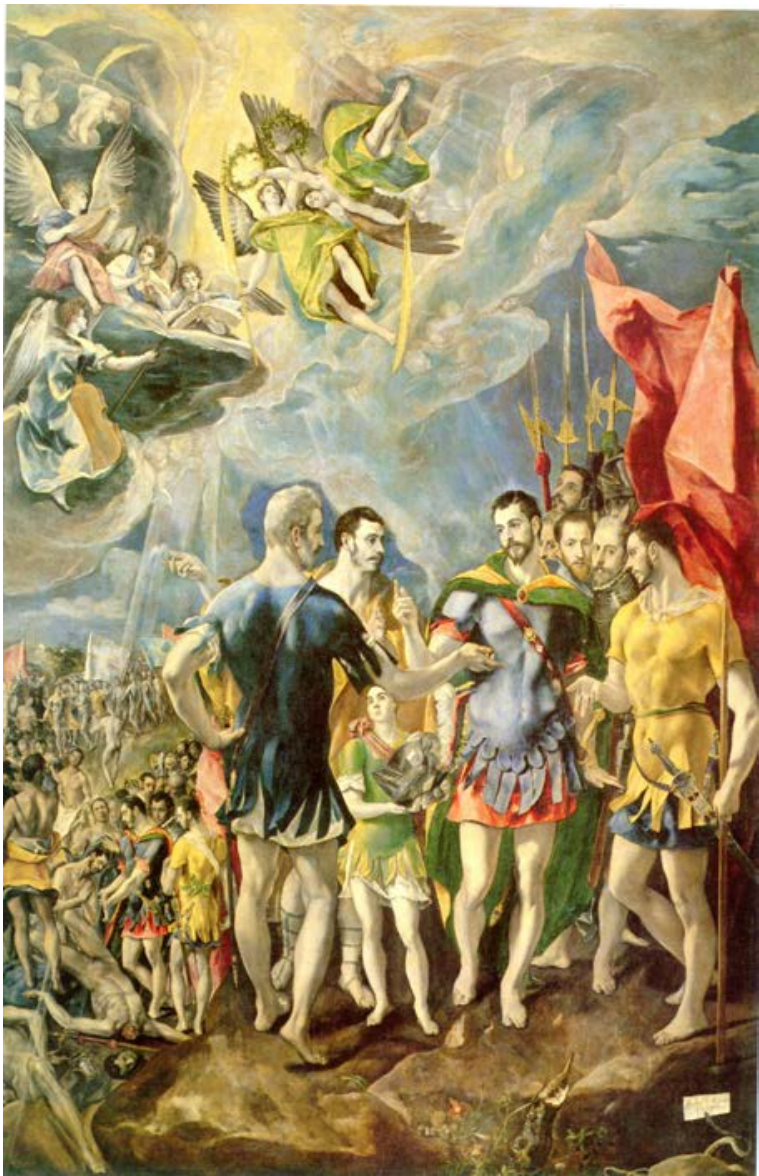

La verdad es que la fama del cretense como pintor genuinamente religioso no se extinguió tan pronto como se ha venido considerando, a causa de las estridencias y extravagancias de algunas de sus creaciones extremas. Esta opinión fue tardía y solo empezó a cundir y extenderse a fines del XVII y durante todo el XVIII gracias a los escritos de Jusepe Martínez y Antonio Acisclo Palomino, en el momento en que triunfaban las aparatosidades y efectismos teatrales y decorativos de la pintura barroca. Pero hasta entonces no había sido así. Francisco Pacheco en 1649 no podía excluir a El Greco "del número de los grandes pintores, viendo algunas cosas de su mano tan relevadas y tan vivas en aquella su manera, que igualan a las de los mejores hombres" (Pacheco, 1990, p. 404). Incluso antes, en 1639, había escrito Baltasar Gracián en El Héroe, probablemente refiriéndose a El Greco: "Vio el otro galante pintor que le habían cogido la delantera Ticiano, Rafael y otros. Estaba la fama más viva cuando ellos eran muertos. Valióse de su invencible inventiva: dio a pintar a lo valentón. Objetaronle algunos el no pintar a lo suave y polido y satisfizo que quería ser el primero en aquella grosería que segundo en delicadeza" (Gracián, 2011, p. 85). Y el jesuita Antonio Quintanadueñas, asesor iconográfico de Pacheco, describiendo en 1651 el milagro operado en el Entierro del conde de Orgaz, pintado por el cretense en Santo Tomé de Toledo, decía: "Se puso un grande y bellísimo quadro en que se pinta el milagroso suceso, pincel superior del célebre Griego Dominico Teocópuli (sic)" (Álvarez Lopera, 2005, p. 432).

Opino que se ha exagerado igualmente al decir que la pintura de Theotocópuli solo era entendida y gustada por el círculo de sus amigos humanistas e intelectuales toledanos, desde luego casi todos ellos sacerdotes e incluso profesores de teología y derecho canónico, como don Diego y don Luis de Castilla, Antonio de Covarrubias, Pedro Salazar de Mendoza y Martín de Zayas, a los que habría que añadir algunos clientes y coleccionistas de la corte. Se olvida, sin embargo, que muchos de los mayores encargos le fueron hechos por el arzobispado, el cabildo de la catedral, los monasterios masculinos y femeninos, las parroquias y cofradías radicadas en ellas, y que las pinturas devocionales de mediano y pequeño formato se las rifaban clientes particulares de todo tipo y condición social. Que a algunos de los cuadros, como El Expolio, de la sacristía de la catedral de Toledo, y La Virgen de la Caridad, del santuario del mismo nombre en Illescas, se les censurase por contener errores de carácter iconográfico no es argumento válido para demostrar que El Greco hubiera introducido en ellos elementos verdaderamente erróneos o escandalosos y que no gustasen a los comitentes y al público devoto. Lo primero era únicamente un pretexto para no tener que pagar las exorbitantes sumas de dinero que el cretense ponía por precio de sus lienzos, muy por encima de los que solían cobrar los pintores toledanos coetáneos; además el poner censuras era incumbencia de los teólogos y hagiógrafos, como aseguró el pintor conquense Antonio Gómez, tío del arquitecto Juan Gómez de Mora, uno de los peritos convocados en la última tasación del cuadro de la Virgen de la Caridad. En cuanto a lo segundo, me parece inconcebible que El Expolio (Fig.8), una de las pinturas de Theotocópuli más cargadas de emoción, sentimiento y empatía con la figura de Cristo, desagradase a los eclesiásticos del cabildo toledano y al resto de los que lo contemplaran. Por otra parte, si El Greco y su hijo Jorge Manuel hubieran sido excesivamente tibios y displicentes en dejar de cumplir sus obligaciones como cristianos, el Consejo de gobierno del arzobispado de Toledo, quien, por decisión del cardenal Gaspar Sandoval y Rojas, debía de- 
signar, después de haberlos examinado, a los oficiales con quien se había de contratar la factura de retablos y pinturas de las parroquias nuevamente constituidas, no hubiera elegido en 1602 para ese menester a ambos, padre e hijo, pese a ser "extranjeros".

Los muchos pleitos en que se vio envuelto El Greco por motivo de los elevados precios que cobraba por sus pinturas no obedecieron exclusivamente a su obsesión por afanar dinero, sino a su carácter terco y pleiteador, de ascendencia familiar, y a su orgullo de artista que estaba decidido, a todo trance, a defender la superioridad de la pintura, no reconocida en España como arte liberal sino reputada como oficio mecánico, y, por ello, sometida al tributo de la alcabala. Prueba de que no solo pleiteaba por su propio provecho es la anécdota que cuenta $\mathrm{A}$. Palomino en la vida del pintor Luis Tristán, aprendiz del cretense, a quien mandó dar

Figura 8. El Greco: El Expolio de las vestiduras, 15771579. Toledo, Sacristía de la Catedral.

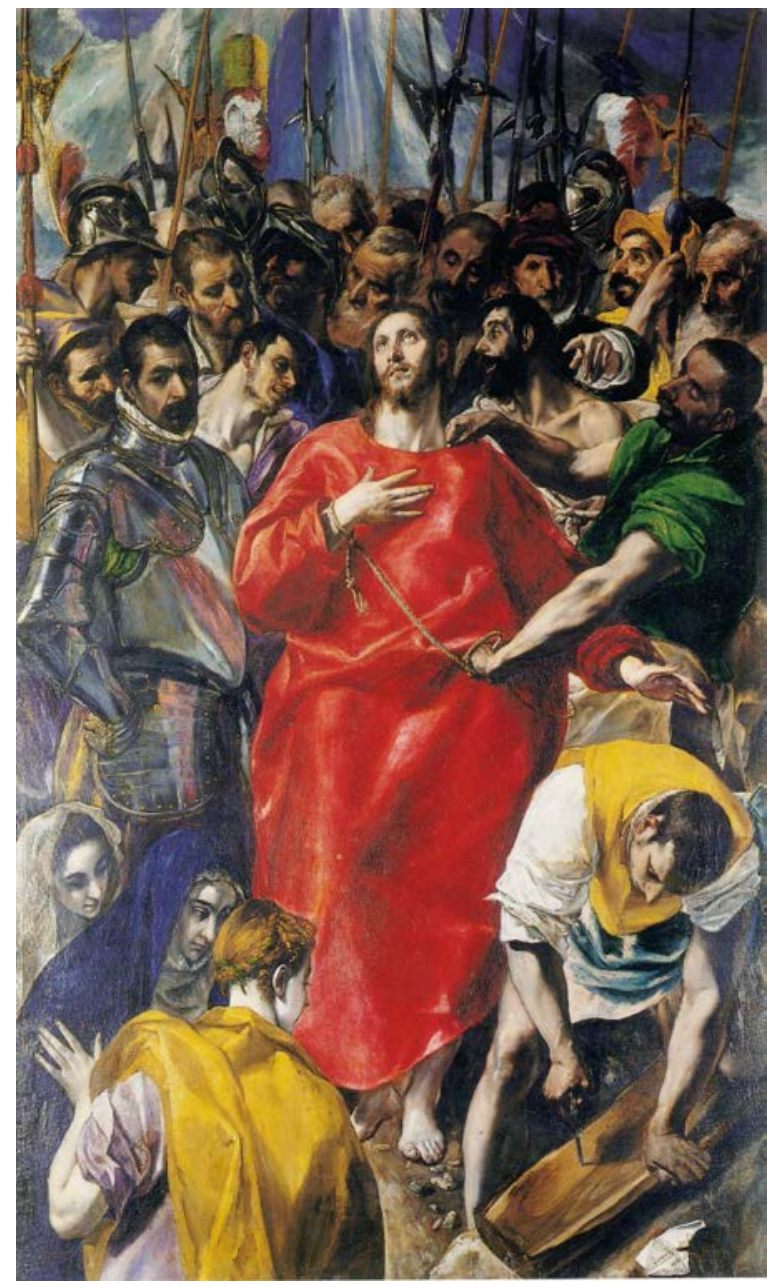

de palos por haberse contentado con pedir solamente doscientos ducados por una pintura de la Sagrada Cena, que a los monjes del monasterio de La Sisla, que la habían contratado para el refectorio, les parecía exagerada. También habría que revisar la supuesta avaricia y el afán de ostentación, lujo y sibaritismo del cretense. En cuanto a lo primero, si bien es verdad que ganó fabulosas cantidades, también lo es que el pago de las tremendas deudas contraídas con algunos de sus amigos, como el doctor Angulo y otros, que le adelantaban dinero como fianza de las incontables y costosas obras a que se comprometía, terminó al final de su vida por conducirle casi a la bancarrota, de suerte que él y su familia llegaron a vivir con graves escaseces y muchas dificultades económicas. Conviene aquí reseñar que Theotocópuli fue incluso generoso con algunos de sus clientes, como don Luis de Castilla, con quien concertó los retablos y pinturas de la iglesia de Santo Domingo el Antiguo, a quien, por no haber regateado el precio acordado por ellas, 1.500 ducados, le condonó nada menos que una tercera parte de ellos. En cuanto al anhelo de lujo y ostentación, cierto que alquiló, en dos períodos de las últimas décadas de su vida, las casas que tenía en Toledo don Juan Fernández Pacheco, marqués de Villena, por un abultado precio de 54 ducados mensuales. Pero debe tenerse en cuenta que tuvo que invertir mucho dinero en acomodarlas, pues estaban deshabitadas desde hacía tiempo $y$, además, le eran absolutamente necesarias no solo para alojar a su familia, que se había acrecentado con la aparición en Toledo de su hermano Manoussos, el casamiento de su hijo Jorge Manuel, con sus respectivos criados y sirvientas, y sobre todo para instalar en ellas el taller con sus aprendices, los almacenes para depositar los cuadros terminados y los abocetados, así como la colección de planos, dibujos, modelos de barro y los libros de su copiosa librería. Lo que cuenta Jusepe Martínez de que "gastó en demasía y ostentación de su casa hasta tener músicos asalariados para, cuando comía, gozar de toda delicia" (Martínez, 1806, p. 183) no está documentado y parece una invención tardía del pintor y escritor aragonés.

Quisiera en este momento subrayar un aspecto poco conocido de la vida de nuestro personaje: la inesperada llegada a Toledo, el año 1603, del hermano mayor, Manoussos, casi de setenta y cinco años, consumido y enfermo. No vino solo sino acompañado de un grupo de griegos, de diferente origen y condición, que se juntaban en el arrabal de Santiago. Todos habían arribado a España y obtenido licencia del Nuncio de su Santidad y de la Santa Cruzada a fin de recabar limosnas en distintos puntos de la península con objeto de 
pagar el rescate de parientes que se encontraban en poder de los turcos. Manoussos concretamente vino para conseguir por ese medio el rescate de la mujer e hijo de su amigo Tomás Trecello, cautivos en Nicosia (Chipre), por cuanto se había comprometido a ello, como albacea testamentario, cuando aquel falleció. Por desgracia Manoussos murió el 13 de diciembre de 1604, seguramente sin haber conseguido su pretensión. Según atestigua su partida de defunción en la parroquia de Santo Tome: "Fallesció Manuel, griego, no hizo testamento, enterróse en San Xristobal. Recibió todos los sacramentos" (San Román, 1982, p. 321). En todo caso tanto Dominico como Jorge Manuel siguieron atendiendo a muchos de aquellos desgraciados griegos y creo que no solo por un sentimiento de humanidad hacia sus compatriotas, sino también como un acto de caridad cristiana. Decía un precepto de Las Constituciones de los Apóstoles, libro que poseía y leería El Greco: "Recordad las palabras del Señor y acoged a quienes por la fe son perseguidos y huyen de ciudad en ciudad. En efecto, conscientes de que el espíritu está bien dispuesto pero la carne es débil, huyen y aceptan la confiscación de sus bienes para conservar en ellos el nombre de Cristo sin negarlo. Procuradles todo lo necesario y cumplid el mandamiento del Señor" (Clemente de Roma, 2010, p. 343) 5 .

Otro de los indicios que se han barajado para argumentar que Theotocópuli no albergaba convicciones religiosas firmes es el de que se unió ilegítimamente a Jerónima de las Cuevas, a la que no mencionó como esposa en su testamento sino solo como madre de su hijo Jorge Manuel (Fig. 9). Cierto que no se ha encontrado hasta ahora la partida de su matrimonio con ella en los archivos parroquiales toledanos, pero acaso el no señalarla el cretense como su legítima mujer en el testamento se debió a que daba el matrimonio por sobreetendido, habida cuenta del mucho tiempo que había transcurrido desde que falleció la joven Jerónima. Actualmente se maneja la razonable hipótesis de que, habiendo abandonado a su mujer legítima en Candía, como ignoraba si había muerto, de haberse casado de nuevo por la iglesia podía ser acusado de bigamia ante el Santo Oficio, el cual, si era tolerante con el adulterio, no lo era de ninguna manera con la bigamia. Se ha documentado que Jerónima, soltera de unos veinte años en 1561, podía ser hermana de Juan de las Cuevas. Pues bien, este se había casado con Petronila de Madrid, hermana a su vez del párroco de Santo Tomé, el que había encargado al cretense la pintura del Entierro del conde de Orgaz. Por consiguiente El Greco, quizá a través de este último, había llegado a conocimiento y trato con su joven sobrina.
Figura 9. El Greco?: La dama del armiño, Jerónima de las Cuevas? 1577-1580. Glasgow, Art Gallery.

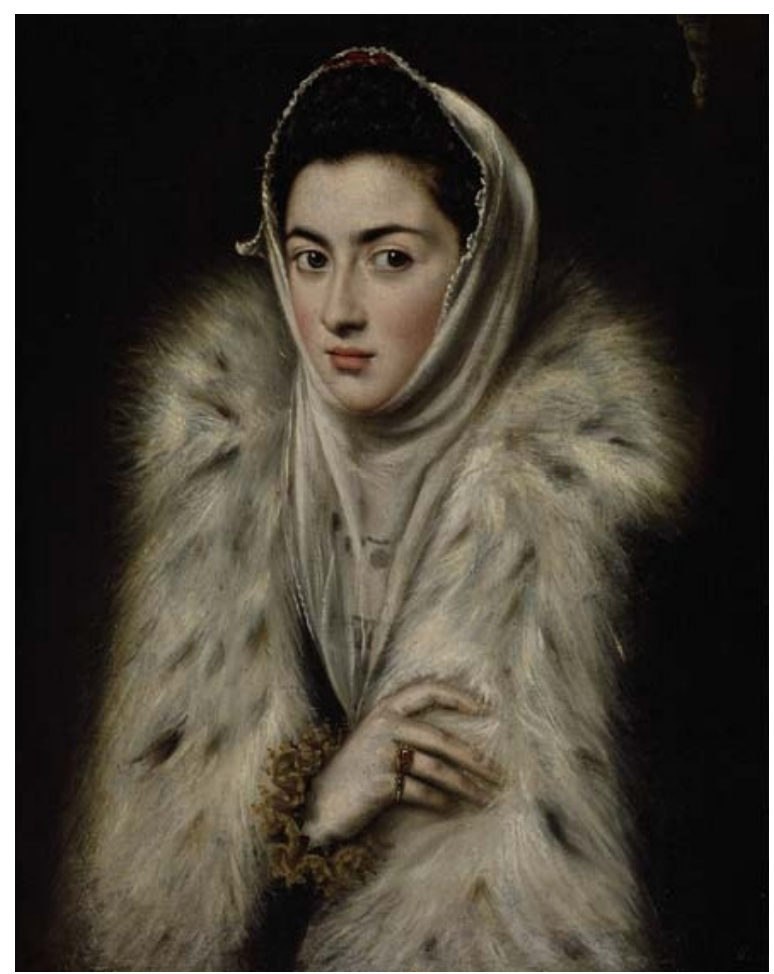

En virtud de ello Jorge Manuel se había prestado a ejercer la curaduría de Manuel de las Cuevas, sobrino de Jerónima, mientras no alcanzó la mayoría de edad. En resumen, Jerónima, aunque de familia modesta del barrio de la Antequeruela, no era una fulana desconocida cuando entró a formar parte de la familia de Theotocópuli.

Igualmente me parece un argumento inconsistente como prueba de insensibilidad religiosa y moral la carencia de pudor en la exhibición de desnudos en algunas de las pinturas y esculturas del cretense, que acaso fueron manifiestos e indecorosos en obras realizadas durante su etapa italiana. Las pequeñas esculturas de Epimeteo y Pandora, totalmente desnudas (Fig. 10), realizadas acaso para la colección privada de Pedro Lasso de la Vega hacia 1598, pueden ser la excepción, pero hechas no por exhibicionismo sino para demostrar el conocimiento de los mitos y de la escultura clásica en una época en que también efectuó para el mismo duque de Arcos el enigmático lienzo de Laoconte y sus hijos. La minúscula talla de Cristo Resucitado que esculpió como remate del tabernáculo del altar mayor del Hospital Tavera no necesitaba paño de pureza, pues apenas podía ser visible el sexo de la diminuta figura vista desde la nave de la iglesia. Cuanto 
a otros desnudos, como los de los resucitados masculinos y femeninos de la Apertura del Quinto Sello, destinada a un retablo colateral de la misma iglesia del Hospital Tavera, ya señaló el doctor G. Marañón su intersexualidad y el nulo efecto de excitación sexual que su visión podía producir. En cualquier caso, la doctrina moral de la época sobre la representación del desnudo en el arte no era, ni mucho menos, tan rígida y cerrada como se ha supuesto. Una consulta convocada al efecto para examinar y dictaminar sobre este asunto fue convocada en 1532, asistiendo a ella varios catedráticos de moral de las universidades de Salamanca y Alcalá; pues bien, uno de ellos, el maestro Joseph de la Cerda, opinaba: "Pinturas desnudas ha usado la Iglesia de los mártyres y historia antigua, donde o la hermosura nos mueve a la alabança del Criador o los tormentos a la imitación del sufrimiento. De suerte que, secundum dar el pincel miembros desnudos donde se esmere la valentía del arte no lo tengo por pecado, pero quando se pinta la misma torpeza cuya representación más incite a apetito a que se admire el entendimiento, juzgo que es pecado mortal" (Calvo Serraller, 1981, p. 234.)

A partir de agosto de 1612, encontrándose Domenico Theotocópuli ya viejo, agotado y enfermo, comenzó a pensar en su próxima muerte y encomendó

Figura 10. El Greco: Epimeteo y Pandora, 1600-1610. Madrid, Museo Nacional del Prado.

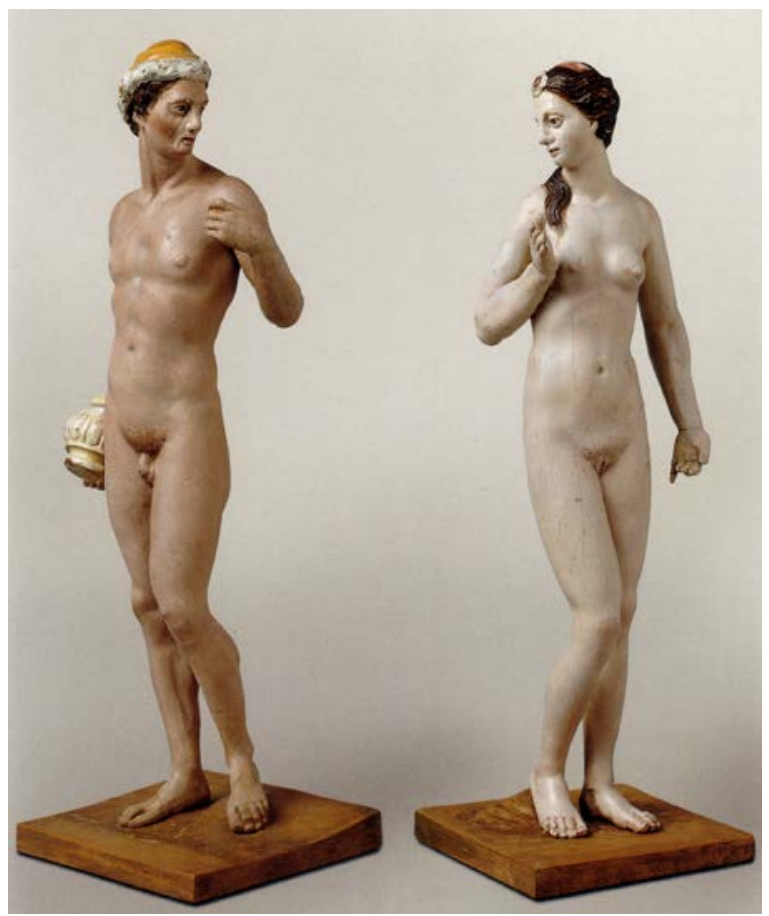

a su hijo Jorge Manuel que le buscase cristiana sepultura en la iglesia del monasterio de Santo Domingo el Antiguo. Las religiosas benedictinas, de las que el cretense debía guardar grato recuerdo, concertaron darle para ello una bóveda o cripta sita por debajo de uno de los altares laterales de la iglesia, tomando por precio de esta donación el compromiso de Jorge Manuel de hacerles el monumento del Santísimo para el Jueves Santo de ese año. El Greco, agotadas ya sus pocas fuerzas, no tardaría en otorgar, el 31 de marzo de 1614, poder a su hijo para que, en su nombre, dispusiese el testamento legal. Y ya en el poder mencionado se expresa diáfanamente la voluntad de Domenico de morir como cristiano católico romano: "Estando echado en cama enfermo de enfermedad que Dios nuestro señor fue serbido darme... creyendo e confesando como confieso todo aquello que cree y confiesa la santa madre iglesia de Roma y en el misterio de la Santísima Trinidad ${ }^{6}$, en cuya creencia protesto vibir e morir como bueno fiel católico cristiano... digo que por quanto la gravedad de mi enfermedad yo no puedo hacer ni otorgar ni hordenar mi testamento como conbiene a el serbicio de Dios Nuestro Señor e salbación e descargo de mi conciencia, e le tengo tratado e comunicado con Jorge Manuel mi hijo e de doña Jerónima de las Cuevas..." (San Román, 1982, pp. 199-202). Dispone en este breve poder que sean albaceas testamentarios su hijo, su amigo don Luis de Castilla y el padre fray Domingo Benegas, fraile profeso del monasterio de San Pedro Mártir. Supongo que la amistad y trato con este fraile dominico venía de antiguo, pues de lo contrario no lo hubiese nombrado albacea, e incluso presumo que fue él quien le administró los últimos sacramentos. De que los recibió no hay duda ninguna, pues así lo registra el libro de entierros de la parroquia de Santo Tomé, a la que pertenecía El Greco como feligrés: "En siete de abril de 1614 fallesció Domenico Greco, no hizo testamento, recibió los sacramentos, enterróse en Santo Domingo el Antiguo, dio velas" (Foradada y Castán, 1876, p. 153).

Algunos estudiosos sacaron precipitadamente la conclusión de que, al no haber hecho el definitivo testamento y al no haber dado más que un manojo de velas para el túmulo, Theotocópuli no ordenó hacer funeral ni decir misas por su alma ni ser enterrado como cristiano. Pero esto viene desmentido por el testamento legal que algo más de dos años después, el 26 de enero de 1616, otorgó su hijo Jorge Manuel, como le había ordenado su padre en el poder que le dio para ello. El retraso fue debido a que, acosado el hijo por las deudas de su padre, que tuvo que ir pagando lentamente, no quiso otorgar el 
definitivo testamento hasta haber solucionado antes aquel problema económico en lo posible, y por eso quiso justificar el retraso incluyendo en el testamento todo lo que había gastado en las honras fúnebres y en el entierro de su progenitor para detraerlo de su propia herencia. Fueron aquellas honras las habituales e incluso más solemnes que las ordinarias, a saber: "Una misa cantada con diácono y subdiacono y bigilia y su responso en la iglesia de Santo Domingo el Antiguo....; los tres días siguientes se le hizo un novenario diciendo en cada uno de ellos una misa cantada en el dicho monasterio de Santo Domingo con diácono y subdiacono y bigilia y responso....; se le dixo su cabo de año en el dicho monasterio de Santo Domingo el Antiguo, el qual hizieron veinte y quatro frayles de la horden de San Francisco....; se le dixeron diez misas de alma en los altares privilegiados de San Pedro Martir y del monasterio de la Santísima Trinidad de esta ciudad de Toledo....; se han dicho cien misas reçadas por el alma de dho. mi padre, dando la quarta parte a la parroquia [de Santo Tomé] y las restantes en el dho. Santo Domingo donde el susodicho está depositado". Por lo que hace a la conducción del cadáver de El Greco desde su casa y el enterramiento en Santo Domingo el Antiguo añade el testamento: "El día de su enterramiento le acompañaron y enterraron su cuerpo la cofradía e cofrades de la Caridad de esta ciudad con su paño..., le acompañó la cruz e clérigos de la iglesia parroquial de Santo Tomé de donde el susodicho era parroquiano..., le acompañó la cofradía e cofrades de las Angustias que celebra en el monasterio de San Pedro Mártir" (San Román, 1982, pp. 213-216).

El Greco y su hijo concertaron hacer un altar y retablo por encima de la bóveda o cripta destinada a su sepultura y a la de los miembros de la familia. Después del fallecimiento de su padre, Jorge Manuel eligió la pintura que había de presidir el retablo, que fue la Adoración de los Pastores (Fig.11), tema bíblico que Domenico había interpretado muchas veces y que para él debía ser fundamental como pintor, puesto que en este misterio del nacimiento de Cristo en Belén de Judá, lo que era absolutamente invisible e irrepresentable, es decir Dios, se hizo visible, mensurable y tangible, es decir representable mediante la imagen, en la figura humana de su Hijo. Esto era lo que implícitamente justificaba el uso de imágenes de pintura y escultura para representar la divinidad invisible, cosa que los judíos rechazaban, y ese argumento es el que utilizó el mártir San Justino (+161 d. C.) en su Apologia I/ frente a judíos y paganos, apología que Thetocópuli tenía en su biblioteca. En el cuadro El Greco se auto-
Figura 11. El Greco: Adoración de los pastores, 16121614. Madrid, Museo Nacional del Prado.

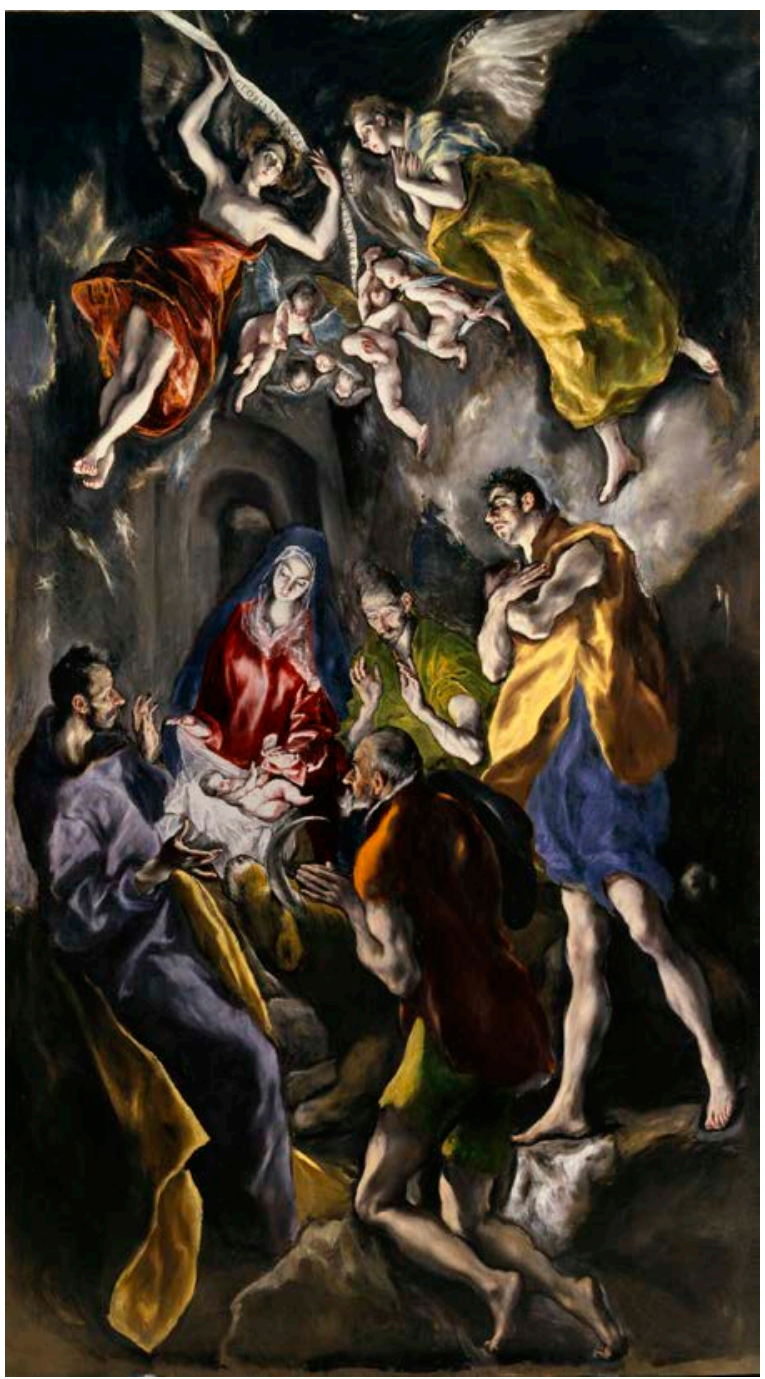

rretrató viejo, consumido y vacilante, en la figura del pastor que se acerca al Niño Jesús en actitud de reconocimiento y adoración, juntando sus manos sobre el pecho, mientras que sus demás compañeros abren más bien sus brazos en gesto de sorpresa. Así, al menos, opinan la mayoría de los estudiosos, que fechan la pintura entre 1612-1614, frente a los que la quieren situar hacia 1607.

Tras el fallecimiento de su padre, Jorge Manuel realizó dos inventarios de sus bienes, entre ellos el de los libros que formaban su biblioteca. En el de 1614 figuran en ella once volúmenes de contenido religioso: Antiguo y Nuevo Testamento, en cinco tomos; Constituciones de los Apóstoles; San Justino mártir, Apologías; Oraciones de San Juan Crisósto- 
mo; Homilías de San Basilio el Grande; San Dionisio De Jerarquía Celeste; Cánones y dogmas del santo y ecuménico Concilio de Trento, todos ellos escritos en griego. En el inventario de 1621 se añadieron otros dos: Flos Sanctorum, seguramente la vida de los santos publicada en 1599 por Alonso de Villegas en Toledo y la Historia Pontifical, partes primera y segunda. La escasa presencia de libros religiosos es otro indicio, según algunos, del escaso o nulo interés de El Greco por estos asuntos; a lo más se ha pensado que se ayudaría de ellos para concretar los temas iconográficos - que barrunto que derivan más de la revisión continua de grabados y estampas y de una tradición que en Italia y España estaba desde hacía tiempo perfectamente codificada- pero no para su conceptuación intelectual de la pintura y escultura, que se haría patente exclusivamente en las notas marginales conservadas solo en dos de sus libros, $\mathrm{Vi-}$ trubio, en traducción de Daniele Barbaro, y las Vidas de los artistas italianos, de Vasari. Sin negar que el cretense partía del concepto aristotélico de la pintura expresado en su Poética como imitación de la realidad visible, ha de considerarse, sin embargo, que el propio Theotocópuli parece que opinaba audazmente que la pintura era capaz de representar igualmente lo trascedente e invisible: "La ymitación de los colores que tengo yo por la mayor dificultad, pues es engañar a los sabios con las cosas aparentes... no sucede en la escultura... pues la pintura trata de lo imposible... digo que essendo las dos artes [copia de la naturaleza] e que la escultura non se extiende más que a la superfizie, la pintura a todo se obliga" (Marías y Bustamante, 1981, p. 241).

Presumo que precisamente para poder captar lo sobrenatural e invisible con los únicos medios con que humanamente parece posible, es decir mediante la potenciación de los colores y de la luz de que se componen y que los manifiesta, El Greco pudo servirse de algunas de las ideas con que los padres de la iglesia griega primitiva abordaron este tema, especialmente los de la escuela de Alejandría y Capadocia, como Basilio el Grande, Juan Damasceno o Juan Crisóstomo. No es casualidad que obras de estos autores figuraran en su librería, y no creo que en ella estuvieran solo de adorno o como demostración de su origen griego y del dominio de la lengua griega de que tanto se pavoneaba ${ }^{7}$. Bastantes estudiosos han manifestado su curiosidad por averiguar el impacto que en el cretense pudo dejar la lectura concreta del libro del Pseudo Dionisio Areopagita, De Coelesti Hierarquia, que en los inventarios de la biblioteca del cretense viene, como era tradición, atribuido a San Dionisio. Sin embargo se ha averiguado que su autor fue un personaje anónimo del siglo $\mathrm{V}$, quien compuso un cuerpo de doctrina que tuvo gran repercusión durante la Edad Media hasta el siglo XVI, cuando se desveló que no era San Dionisio, discípulo de San Pablo. Su doctrina está contagiada de conceptos procedentes de Porfirio Plotino, quien para explicar la diversidad del universo a partir de la unicidad de Dios (Enás), se sirvió de la alegoría de la luz. Así como la Enéadas o elementos constitutivos y ordenadores del cosmos son emanaciones del Uno y se escalonan de arriba a abajo hasta llegar a la pura materia, de la misma manera la luz se desintegra en los colores que son destellos o irisaciones de la pura luz que los contiene, luz que amortigua de manera escalonada hasta llegar a la oscuridad de las tinieblas ${ }^{8}$. El Pseudo Dionisio y los padres orientales utilizaron continuamente el símbolo de la luz para explicar la esencia de Dios, pues este se había manifestado a Abrahán en la zarza ardiente, cuya luz no se extinguía ni la zarza se consumía, y había señalado el nuevo nombre con que quería ser llamado en adelante: Yawhé = "soy el que soy", el Absoluto, en lugar de Elohin (Éxodo, 1, 16). Así se expresa, por ejemplo, el Pseudo Dionisio: "Todo viene de arriba, desciende del Padre de las Luces, cuya luz se difunde copiosamente sobre nosotros y con su poder unificante nos atrae y nos lleva a lo alto..., invoquemos a Jesús, Luz del Padre".... O en otro pasaje: "Las jerarquías celestes... hacen que sus miembros sean imágenes, espejos transparentes que reflejan el brillo incandescente de la Luz primera, que es Dios mismo. Luego que sus miembros han recibido la plenitud de la luz, de su divino resplandor, trasmiten generosamente la luz de Dios a aquellos que les siguen en escala " (Pseudo Dionisio, 1995, pp. 119-120 y p. 133).

Citaré, en abundancia de lo dicho sobre la luz como símbolo visible de Dios, otro párrafo de San Juan Damasceno: "De la misma manera que el fuego y la luz existen a la vez y no primero el fuego y después de este la luz y los colores, sino simultáneamente, y así como la luz que proviene del fuego siempre sale de él y de ningún modo se aleja de él, así el Hijo que procede del Padre, es engendrado y no se aleja de él sino que siempre está en él... Ciertamente en el principio Dios hizo el sol y las estrellas, esto es el embellecimiento y orden de la creación visible como alegoría de la invisible. En efecto, quita la luz y todo permanece indistingible en la sombra, no pudiendo mostrar su propia coloreada belleza; la sombra no es una esencia sino un accidente ya que es carencia de luz" (Damasceno, 2003, pp. 80-82). 
Pues bien, El Greco expresa en el rótulo de la Vista y plano de Toledo (Fig. 12) que para pintar a la Virgen y a los ángeles que parecen imponiendo la casulla a San Ildefonso, "para su ornato y hacer las figuras grandes, me he valido en cierta manera de ser cuerpos celestiales, como vemos en las luces que vistas de lejos parecen grandes". La predilección de la luz a la sombra para resaltar los colores de las cosas que aquella hace visibles, se pone de manifiesto en esta otra frase: "La luz del mediodía ralegra et ayuda a mil cosas necesarias et particulares del arte de pintar, como es reflexos, es decir que las sombras que recubren el todo, a las quales cosas tan nezesarias el inconveniente de la luz no es nada, pues con un enzerado [puesto en la ventana] se cumple" (Marías y Bustamante, 1981, p. 228).

Finalmente traigo este otro párrafo del citado Juan Damasceno "Hay ángeles, arcángeles, tronos, dominaciones y otras potencias intelectuales e intelectos, naturalezas puras y sin mezcla como los colores, que siempre están danzando en coro alrededor de la luz primera" (Damasceno, 2003, p. 28). El Greco efectivamente pintó numerosos coros angélicos que en torbeIlino parecen danzar en la parte superior de los lienzos religiosos en que quería distinguir como celeste aqueIla zona y como terrestre la inferior (Fig. 13). Lo que, en resumen, he querido expresar en esta digresión es que Theotocópuli, cuando quería pintar lo imposible, es decir lo sobrenatural, lo trascendente e invisible, se valía de su admirable técnica de mezclar, abrillantar y producir reflejos de los colores a través de los distintos grados de iluminación, usando símbolos muy presentes en la literatura eclesiástica oriental. Pues lo invisible por naturaleza no se puede reflejar de otro modo que con símbolos sensibles, produciendo la impresión de visiones intelectuales de lo divino, que son las únicas de que es capaz el ser humano.

Para concluir este ya largo ensayo voy a hacer algunas observaciones sobre dos lienzos de los últimos años de El Greco, donde el radicalismo de sus visiones se acentúa más si cabe. El primero es el de La Inmaculada (Fig. 14), pintado para el retablo de la capilla de Isabel de Oballe en la parroquia de San Vicente de Toledo. Hasta hace muy poco se tuvo por la pintura de La Asunción de la Virgen, hasta que se descubrió que el tema elegido e impuesto representar a Alessandro Semini fue el de la Inmaculada, por lo que se supone que El Greco hubo de atenerse al primer contrato sin variar el asunto iconográfico, aunque también es cierto que cambió algunas cosas en el conjunto de la capiIla, como la proporción alargada del retablo que había de contener el lienzo, alegando como razón que que-

Figura 12. El Greco: Vista y plano de Toledo, 1600-1610. Toledo, Casa Museo de El Greco.

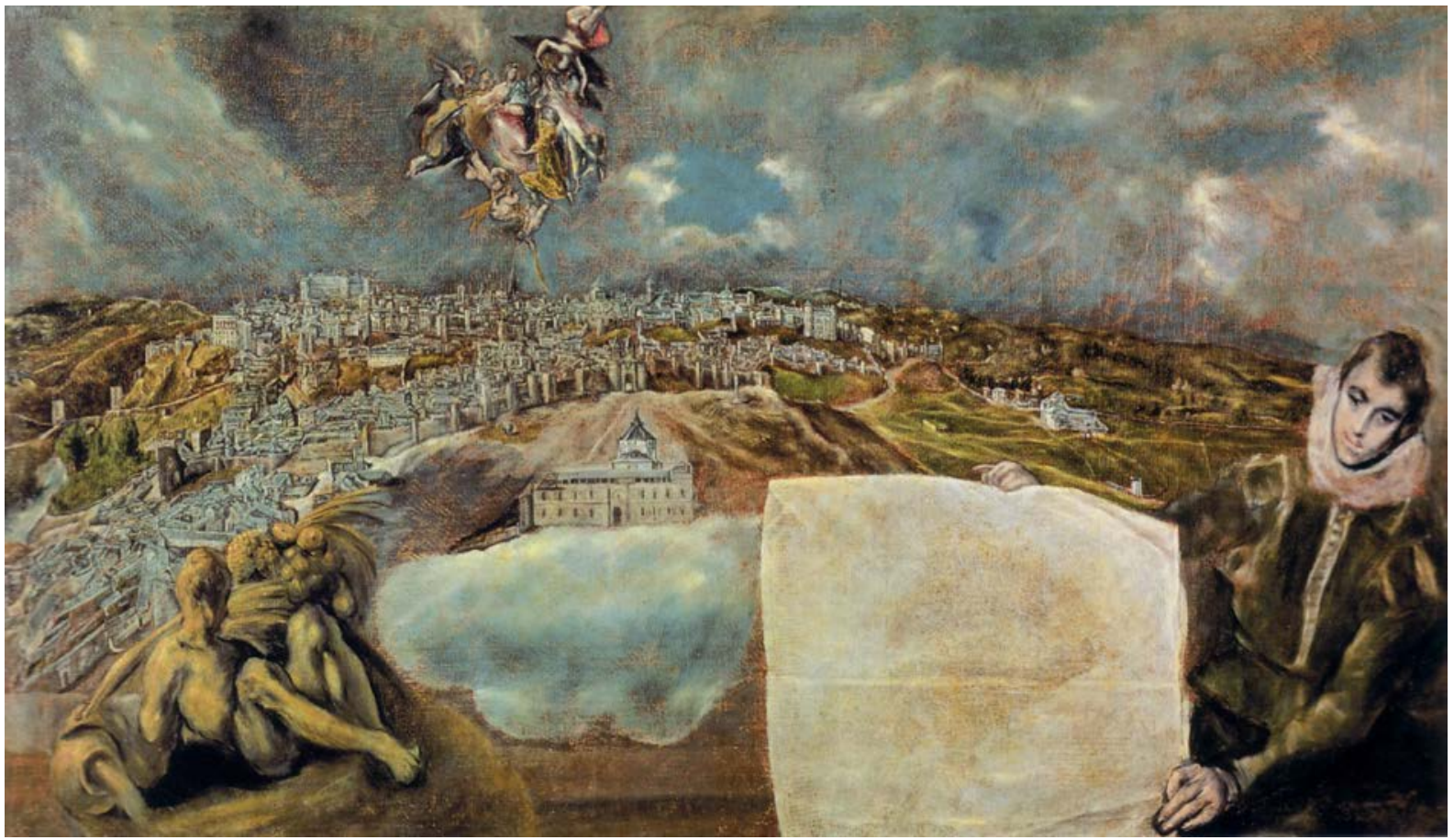


Figura 13. El Greco: Adoración de los pastores [detalle], 1612-1614. Madrid, Museo Nacional del Prado.

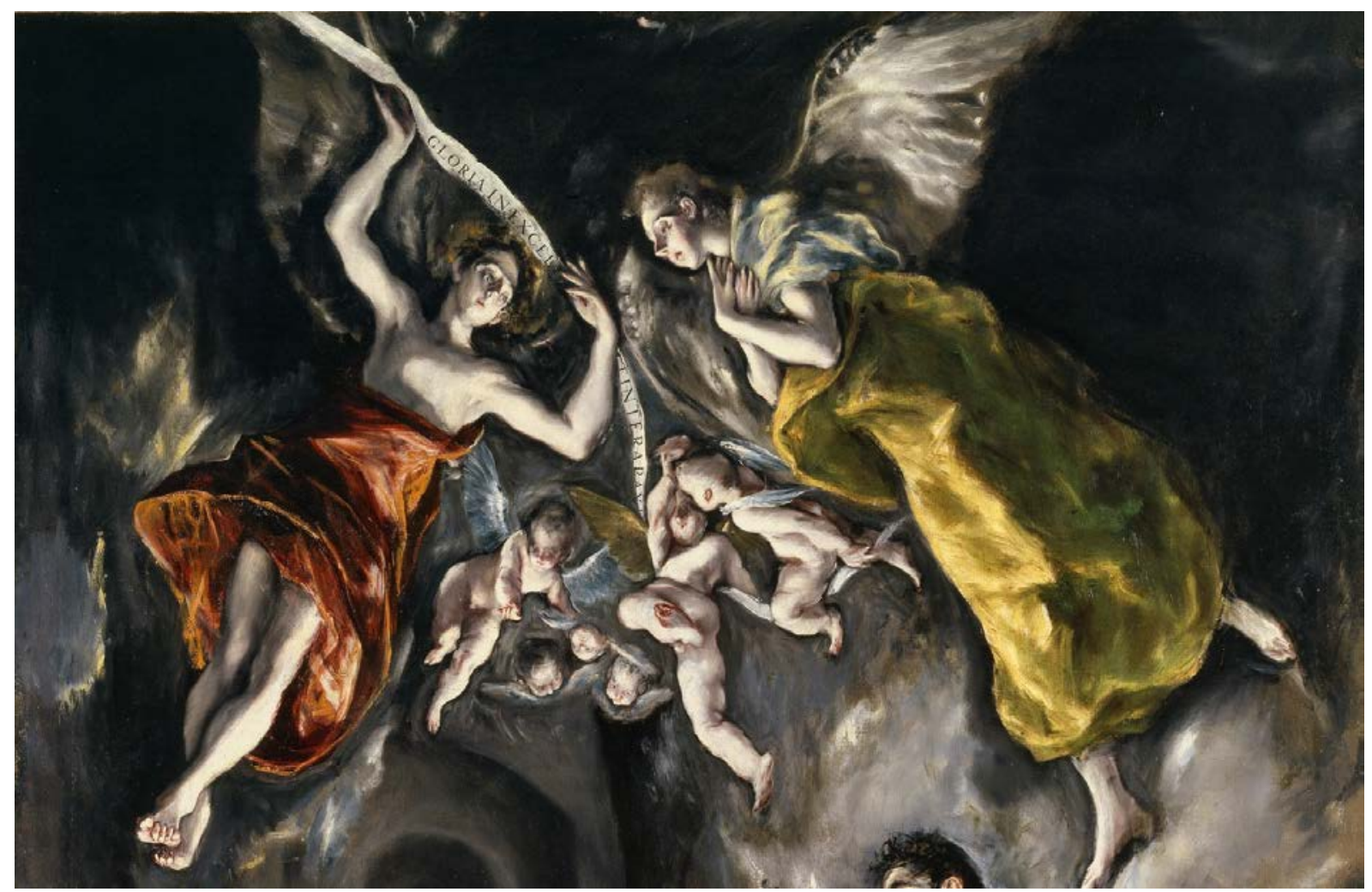

daría el retablo "de fábrica perfecta, no enana, que es lo peor que puede tener todo género de forma" (Marías Franco, 1991, p. 79) ${ }^{9}$. De todos modos, resulta una Inmaculada ambigua, como así lo percibió el poeta Rainer Maria Rilke en su visita a Toledo. En carta de 1912 a su amiga Maria von Thurn und Taxis le dice: "He visto muchas cosas de El Greco en Toledo y cada vez con más penetración y, por último la Asunción en San Vicente: un ángel gigantesco irrumpe oblicuamente en el cuadro, otros dos se alargan tan solo, y de lo que resta de todo eso se origina el puro ascender, y no puede dejar de ser otra cosa" (Pau Pedrón, 1997, p. 251). Encontrándose en Ronda, compuso el célebre poema titulado Asunción de María del que entresaco algunos versos:

"No solo te evades de la vista de tus discípulos a los que queda la suave melancolía de tu vestido.

¡Ayi, tú te quitas también del cáliz de las flores y del vuelo que las aves describen...

Como en el ojo de una aguja quiere enhebrarse en ti la larga mirada mía antes de que te sustraigas a lo visible"
Efectivamente, esta peculiar Inmaculada del cretense difiere notablemente de otras que el pintor realizó, especialmente de la de hacia 1580-1585, ahora en el Museo de Santa Cruz en Toledo (Fig.15). En esta se halla presente, en el ángulo inferior derecho, la figura de San Juan Evangelista que contempla la visión apocalíptica de la misteriosa mujer que contempló en la isla de Patmos, visión que con el tiempo se hizo tradicional de la representación de la Inmaculada Concepción: la Virgen descendiendo sobre una espesa nube, con las manos juntas sobre el pecho, dirige su mirada hacia abajo, hacia el evangelista, y en el paisaje se perciben con claridad los símbolos tradicionales de la Letanía Lauretana. Por el contrario, en la de la capilla Oballe asciende, alargada y cimbreante, con la mirada puesta en el cielo, y los ángeles que la acompañan con sus enormes alas irisadas (los "ángeles-pájaro" de Rilke) también suben y uno de ellos como que apoya y hace de pedestal a María en su Ascensión. Además, el paisaje es similar al de la Vista de Toledo, del Metropolitan Museum de Nueva York, y solo a distancia y casi invisibles aparecen algunos símbolos de las letanías que, por otra parte, eran muy anteriores al santua- 
Figura 14. El Greco: Inmaculada Ovalle, 1608-1613. Toledo, Museo de Santa Cruz.

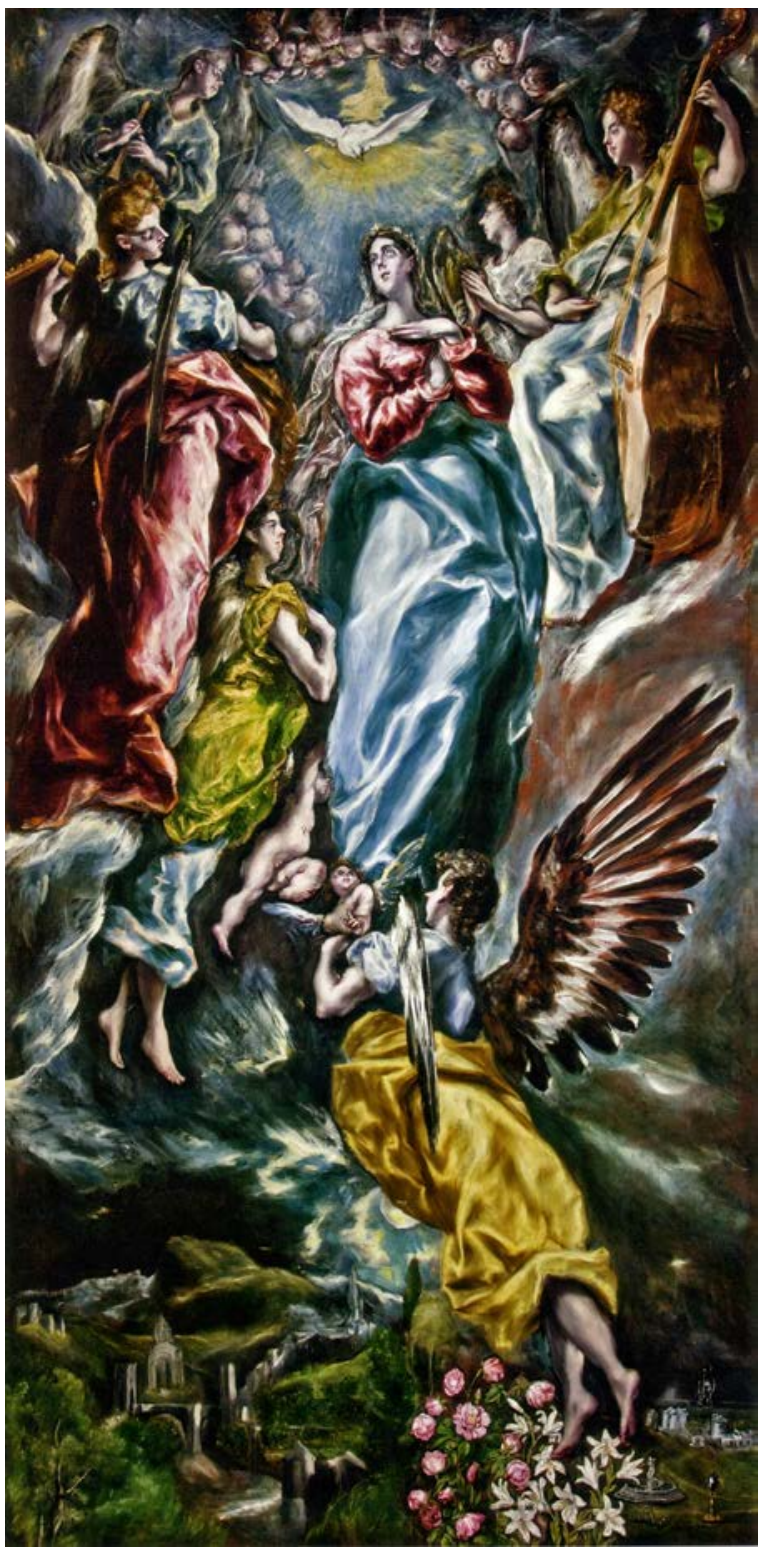

rio de Loreto, donde parece se comenzaron a recitar, pues figuran mucho antes en los padres de la Iglesia, tanto orientales como occidentales, particularmente por Andrés de Creta, referidos a la Asunción ${ }^{10}$.

El artista cretense pintó igualmente la Apertura del Quinto Sello (Apocalipsis, 6, 9-12) en los últimos años de su vida, ya muy cercano a su muerte, con destino al retablo colateral izquierdo de la iglesia del Hospital Tavera de Toledo (Fig. 16). Hoy se piensa con mayor exactitud que Thetocópuli resumió en una sola pintura varios aspectos de la resurrección de los muertos, y no
Figura 15. El Greco: Inmaculada, 1594-1596. Toledo, Museo de Santa Cruz.

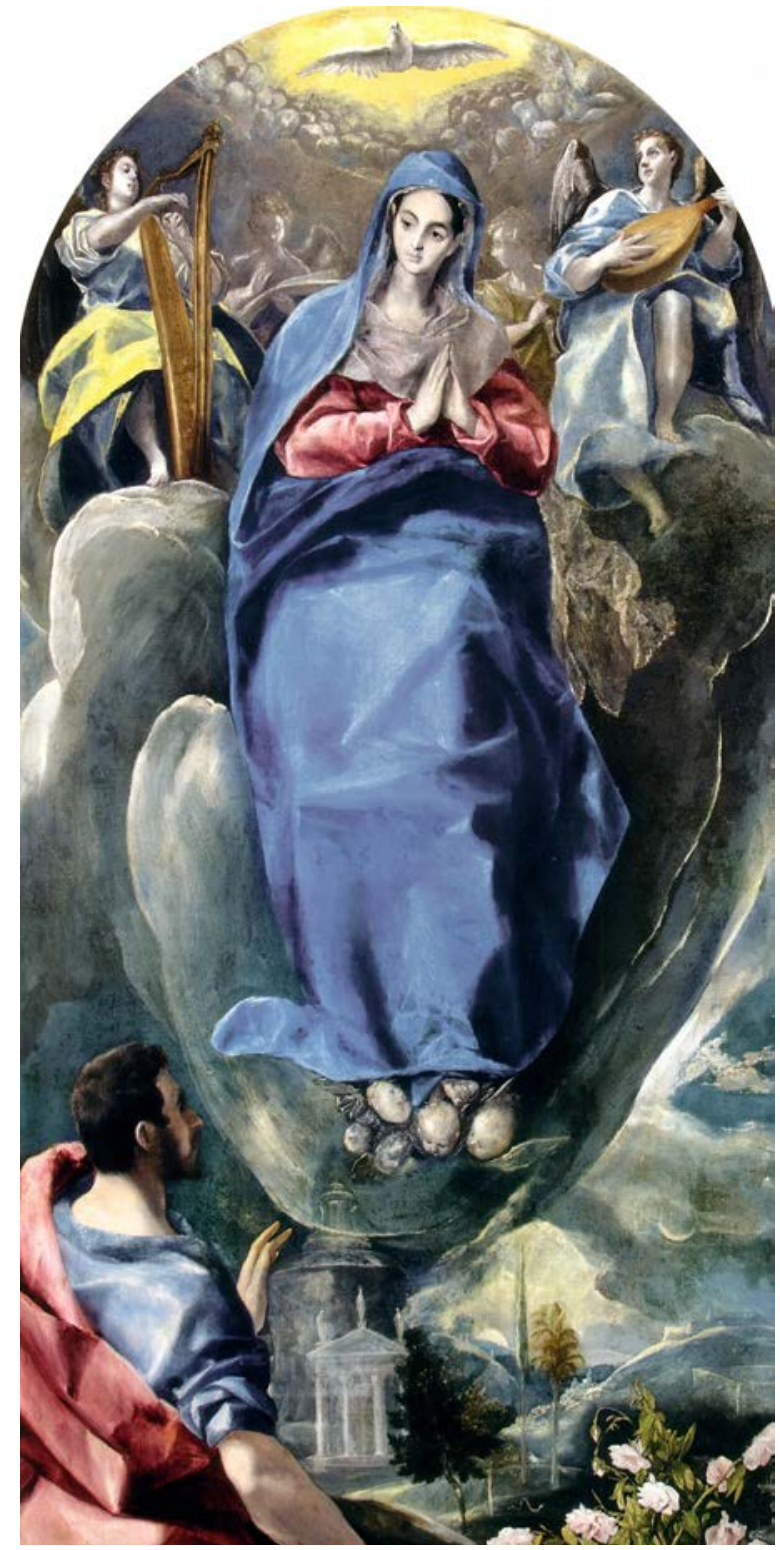

solo el de la mencionada "Apertura", referidos por San Juan en la totalidad de su libro. Convence totalmente que el tema iconográfico fuera elegido para la iglesia de un Hospital, probablemente por el que hizo el encargo a El Greco, Pedro Salazar de Mendoza, amigo del pintor y administrador precisamente del Hospital Tavera, pero no por el hecho, como se ha afirmado alguna vez, de que en dicho centro hospitalario se asegurase la salvación eterna a los enfermos recogidos en él. Los resucitados contemplados en visión intelectual por la enorme imagen de San Juan, destacada, como un 
Figura 16. El Greco: Apertura del quinto sello o Visión de San Juan: los cuerpos resucitados, 1608-1622. Nueva York, The Metropolitan Museum of Art.

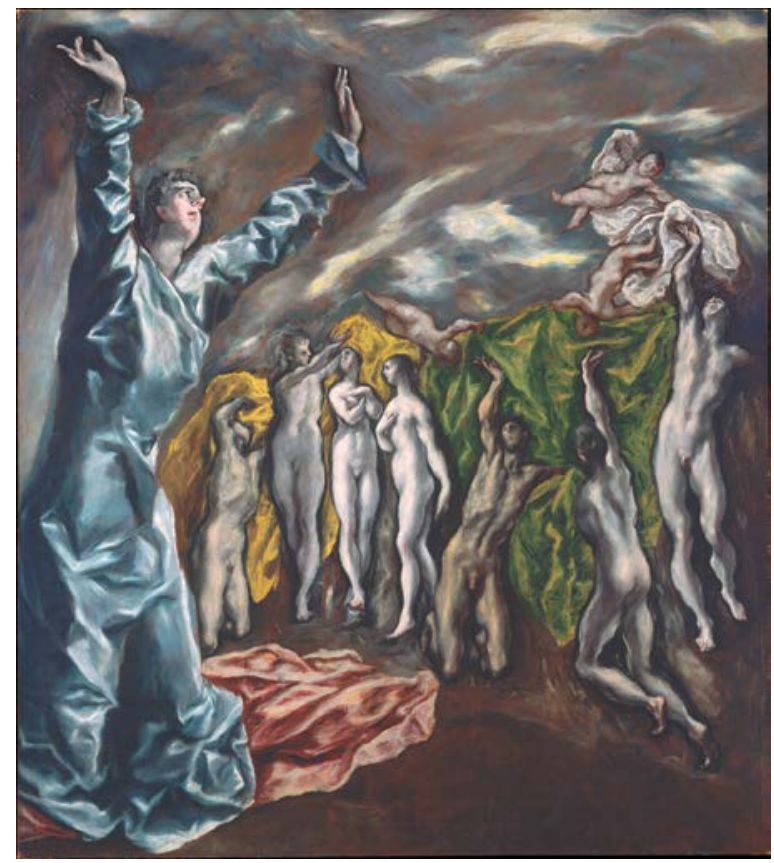

fantasma, en primer plano y a cuyos pies se despliega un manto rojo, son siete, todos completamente desnudos, hombres y mujeres, acabados de salir de sus tumbas, repartidos en dos grupos, amparados mejor que cubiertos por paños de diferente color, amarillo y verde, y únicamente el último de ellos a la derecha levanta el brazo para alcanzar un velo blanco que enarbolan unos angelitos volando sobre un cielo sombrío, cubierto de nubarrones. Cortado por arriba y por los lados, tal como nos ha llegado, el cuadro actual no nos permite resolver el enigma de lo que El Greco quiso pintar, aunque lo presumible es que por encima del cielo anubarrado estuviera la figura de Cristo juez descendiendo para dar comienzo al Juicio Final de la humanidad. Pero ¿qué significado tiene el reparto de los resucitados en dos grupos, el primero al parecer de mujeres cubiertas por el paño amarillo, y el otro grupo de tres, al parecer hombres, cubierto con el paño de color verde? ¿Se trata de las mortajas de los que acababan de surgir de la tumba con los cuerpos que tuvieron? Entonces ¿qué hace el paño rojo tan inmediato a la figura de San Juan que parece vinculado estrechamente a él? Lo único que se me ocurre para explicar los paños de distintos colores es que pudieran simbolizar los distintos grados de méritos adquiridos por cada grupo de los que van a ser juzgados, y conforme a los cuales serán recompensados en mayor o menor proporción en la vida ultraterrena. $Y$ a este propósito termino citando un texto de San Ildefonso, del que había escrito la biografía el mencionado administrador del Hospital Tavera, Pedro Salazar de Mendoza, quien por eso conocía muy bien sus escritos. En uno de ellos dice: "Resucitando los cuerpos santos sin ningún defecto, sin ninguna deformidad, sin corrupción, peso ni traba, en ellos habrá tanta agilidad y luminosidad cuanto lo exija su felicidad. Por eso se dicen espirituales, aunque indudablemente hayan sido auténticos cuerpos, no espíritus, pues así como se dice ahora cuerpo animado sin que por eso sea alma sino cuerpo, así entonces será cuerpo, no espíritu, pero se comportarán como cuerpo celestial" (Ildefonso de Toledo, 1952, pp. 315-316). Y recordemos que como "cuerpo celestial" había representado El Greco a San Ildefonso en el cielo de su Vista y mapa de Toledo.

\section{NOTAS}

[1] Meier Gräfe minifestó estas impresiones suyas sobre Velázquez y El Greco con motivo de un viaje a España efectuado en 1908, que publicó dos años después en el libro Spanische Reise.

[2] De todas las maneras no todos los especialistas están de acuerdo con esta opinión de Panayotakis, barajando distintas fechas para su conversión al catolicismo. Pero de lo que hay ninguna duda es de que ambos hermanos murieron en la fe católica, como lo manifestaron paladinamente a la hora de su muerte, según se dirá más adelante.
[3] Las respectivas medallas llevaban la inscripción: "Domus mea, domus orationis vocabitur" (mi casa es casa de oración), que Jesucristo había pronunciado con motivo de la expulsión de los mercaderes del templo (Mateo, 21, 12-17).

[4] Recientemente el referido Panayotakis ha establecido que el ejemplar de Los Cánones y Decretos del Concilio Ecuménico de Trento, que El Greco tuvo en su biblioteca, era la traducción del latín al griego de la actas del Concilio hecha por Matahios Debaris, humanista procedente de la isla de Corfú que formaba parte del círculo de F. Orsini en el palacio Farnese.
[5] Las Constituciones Apostólicas recopiladas en griego por Clemente de Roma en el siglo IV, eran una suerte de ordenanzas del culto, de las costumbres y de los preceptos morales vigentes en la primitiva Iglesia Griega, pues se compusieron probablemente en Siria hacia el año 380 de la era.

[6] Con esta alusión explícita de El Greco a la Santísima Trinidad quizá quería significar que creía en ella al modo de la iglesia católica romana, es decir admitiendo que el Espíritu Santo procede simultáneamente del Padre y del Hijo, y no solo del Padre, como afirmaba comúnmente la iglesia ortodoxa griega. 
[7] No solo porque firmó sus cuadros con su nombre, apellido y patria en griego, sino que, por ejemplo, en 1582, hizo de intérprete ante el tribunal del Santo Oficio de Toledo en la causa entablada contra el sastre griego, natural de Atenas, Miguel Rizo Calcandil, acusado de hereje y apóstata de la fe católica, prometiendo "interpretar bien y fielmente lo que en ella el reo dijese".

[8] La comparación de la luz desde su plena brillantez hasta la calígine de las

\section{BIBLIOGRAFÍA}

Álvarez Lopera, J. (2005). El Greco. Estudio y Catálogo (vol. I). Madrid: Fundación de Apoyo a la Historia del Arte Hispánico.

Calvo Serraller, F. (1981). Teoría de la pintura del Siglo de Oro. Madrid: Cátedra.

Clemente Romano (2010). Constituciones Apostólicas. Madrid: Ciudad Nueva.

Foradada y Castán, J. (1876). Datos biográficos desconocidos o mal apreciados acerca del pintor Dominico Theotocópuli. Revista de Archivos, Bibliotecas y Museos, VI, 8-9, p. 38.

Gracián, B. (1990). Obras Completas. Madrid: Cátedra.

Ildefonso de Toledo (1952). Obras. Madrid: Biblioteca de Autores Cristianos.

Kagan, R. L. (1984). Pedro de Salazar de Mendoza as Collector, Scholar, and tinieblas, para explicar visualmente el descenso escalonado desde la unicidad del Uno (Dios) hasta la diversidad de los eones que ordenan el cosmos, Enéadas, se encuentra el tomo $\mathrm{V}$ de las Enéadas, de Porfirio Plotino, cap5, párrafo 12.

[9] Me permito recordar al respecto que el pintor cretense, al comentar al Parmigianino en sus notas marginales a las Vidas de artistas italianos de Vasari, escribe: "E no dejaré de arecordar Parmigiano, digo Francisco Parmijano, que

Patron of El Greco. En Brown, J. y Pita Andrade, J. M. (eds.). El Greco: Italy and Spain: proceedings of the symposium held in Toledo, Spain, on 2-4 April 1982. Washington: National Gallery of Art, pp. 85-93.

Maio, R. de (1978). Michelangelo e la Controrifoma, Roma-Bari: Laterza.

Marías, F. y Bustamante, A. (1981). Las Ideas artísticas de El Greco. Madrid: Cátedra

Marías, F. y Salas, X. de (1992). El Greco y el arte de su tiempo. Las notas de El Greco a Vasari. Madrid: Real Fundación Toledo.

Marías Franco F. (1991). El Greco y el punto de vista: la capilla Ovalle de Toledo. Anuario del Departamento de Teoría e Historia del Arte, III, pp. 83-92. parece que solo nasció para mostrar con los yschizos [dibujos] o rascunnos, [rasguños] que si dicono, la svelteza e grazia nelas figuras".

[10]Este personaje, arzobispo de Gortina en la isla de Creta, hacia el año $700 \mathrm{~d}$. C., compuso al menos tres homilías para la fiesta de la Dormición-Asunción de la Virgen, que se celebraba en la isla el 15 de agosto coincidiendo con la vendimia.

Martínez, J. (1866). Discursos practicables del nobilísimo arte de la pintura. Madrid: Real Academia de Bellas Artes de San Fernando.

Pau Pedrón, A. (1997). Rilke en Toledo. Madrid: Trotta.

Pacheco, F. (1990). El arte de la Pintura. Madrid: Cátedra.

Pseudo Dionisio (1995). Obras (2ª ed.). Madrid: Biblioteca de Autores Cristianos.

San Juan Damasceno (2003). Exposición de la fe. Madrid: Ciudad Nueva.

San Román, F. de B. (1982). El Greco en Toledo. Vida y obra. Toledo: Zocodover.

Sigüenza, J. (1963). La Fundación del Monasterio de El Escorial. Madrid: Espasa. 